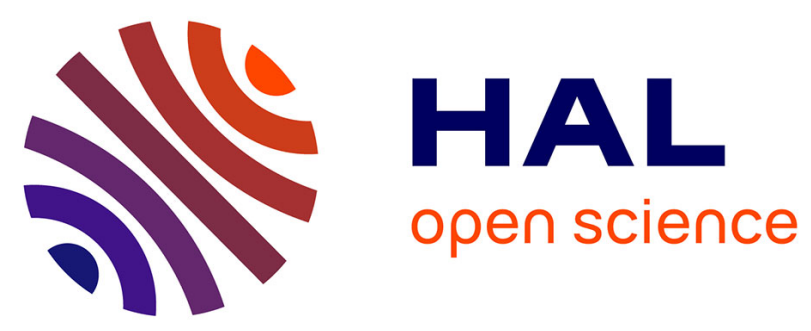

\title{
A comparison of two canopy conductance parameterizations to quantify the interactions between surface ozone and vegetation over Europe
}

A. Anav, L. Menut, D. Khvorostyanov, N. Viovy

\section{- To cite this version:}

A. Anav, L. Menut, D. Khvorostyanov, N. Viovy. A comparison of two canopy conductance parameterizations to quantify the interactions between surface ozone and vegetation over Europe. Journal of Geophysical Research: Biogeosciences, 2012, 117 (3), pp.G03027. 10.1029/2012JG001976 . hal01109261

\section{HAL Id: hal-01109261 \\ https://hal.science/hal-01109261}

Submitted on 27 Jan 2015

HAL is a multi-disciplinary open access archive for the deposit and dissemination of scientific research documents, whether they are published or not. The documents may come from teaching and research institutions in France or abroad, or from public or private research centers.
L'archive ouverte pluridisciplinaire HAL, est destinée au dépôt et à la diffusion de documents scientifiques de niveau recherche, publiés ou non, émanant des établissements d'enseignement et de recherche français ou étrangers, des laboratoires publics ou privés. 


\title{
A comparison of two canopy conductance parameterizations to quantify the interactions between surface ozone and vegetation over Europe
}

\begin{abstract}
A. Anav, ${ }^{1}$ L. Menut, ${ }^{1}$ D. Khvorostyanov, ${ }^{1}$ and N. Viovy ${ }^{2}$
Received 3 February 2012; revised 19 July 2012; accepted 21 July 2012; published 5 September 2012.

[1] The effect of air pollution on vegetation and the consequent changes in atmospheric chemistry are largely under-investigated; a new generation of chemical transport models fully coupled with complex land surface models is needed to better represent the feedbacks between vegetation and atmospheric chemistry. In this context, we coupled at high spatial resolution $(30 \mathrm{~km})$ the chemistry transport model CHIMERE with the land surface model ORCHIDEE to study the regional impact of tropospheric ozone on Euro-Mediterranean vegetation and the consequent changes in biogenic emission and ozone dry deposition owing to modifications in canopy conductance and LAI due to the ozone stress on vegetation. Results for the year 2002 show that the effect of tropospheric ozone on vegetation leads to a significant reduction of about $23 \%$ in the annual gross primary production, followed by a reduction in leaf area index. In addition, results show that CHIMERE does not correctly reproduce the activity of evergreen forests, grassland and crops during winter and fall, and consequently the dry deposition velocity is affected by this wrong pattern. On the other hand, in the coupled model, we have a better representation of vegetation activity during cold months, and the general performance of the model is improved compared to local site observations.
\end{abstract}

Citation: Anav, A., L. Menut, D. Khvorostyanov, and N. Viovy (2012), A comparison of two canopy conductance parameterizations to quantify the interactions between surface ozone and vegetation over Europe, J. Geophys. Res., 117, G03027, doi:10.1029/2012JG001976.

\section{Introduction}

[2] Land surface plays a pivotal role in the Earth system through physical, biophysical and biogeochemical interactions with atmosphere and ocean [Foley et al., 1994; Prentice et al., 2000]. Land-atmosphere interactions include complex feedbacks between soil, vegetation, and atmosphere through the exchanges of water, momentum, energy, and greenhouse gases [Pielke et al., 1998; Arora, 2002], as well as the emission and deposition of several compounds [e.g., Guenther et al., 2006; Lathière et al., 2006; Petroff et al., 2008; Fowler et al., 2009].

[3] The carbon allocation in vegetation biomass depends on several factors including light, water and nutrient availability, and unfavorable conditions that affect or inhibit the plant's metabolism, growth or development.

\footnotetext{
${ }^{1}$ Laboratoire de Meteorologie Dynamique, IPSL, École Polytechnique, Palaiseau, France.

${ }^{2}$ Laboratoire des Sciences du Climat et de 1'Environnement, LSCE, Gif-sur-Yvette, France.

Corresponding author: A. Anav, Laboratoire de Meteorologie Dynamique, École Polytechnique, 91128 PALAISEAU CEDEX, France. (alessandro.anav@1md.polytechnique.fr)

C2012. American Geophysical Union. All Rights Reserved. 0148-0227/12/2012JG001976
}

[4] Several air pollutants provide an unfavorable condition for vegetation growth and may affect plant's metabolism, ecosystem structure and functions in different ways [Heagle, 1989; Heagle et al., 1999; Bergin et al., 2001; Ashmore, 2005; Muntifering et al., 2006].

[5] Air pollutants, for instance, may affect photosynthesis by modifying the amount of incident radiation reaching the top of the vegetation canopies. Specifically, anthropogenic emissions of air pollutants including $\mathrm{SO}_{2}, \mathrm{NO}_{\mathrm{x}}$ and organic compounds result in the generation fine aerosol particles, which both scatter and absorb solar radiation. These aerosols reduce the amount of photosynthetically active radiation (PAR) reaching the surface of the canopy by direct extinction of solar radiation as well as by modifying the albedo of clouds [Bergin et al., 2001].

[6] Considering a more direct effect on vegetation, among air pollutants, tropospheric ozone is known to produce severe damages to plants [Ollinger et al., 1997]; it leads to changes in stomatal behavior resulting in a photosynthesis reduction [Reich, 1987; Wittig et al., 2007] that, in turn, lead to a leaf area index reduction (LAI) [Wittig et al., 2009]. Changes in LAI could be particularly relevant for atmospheric chemistry since the LAI affects both the biogenic volatile organic compound (BVOCs) emissions [e.g., Guenther et al., 2006; Lathière et al., 2006] and deposition processes [e.g., Wesely, 1989; Katul et al., 2011]. 
[7] On one hand, BVOCs play an important role in fuelling the photochemistry of polluted boundary layer and may contribute significantly to severe ozone events [e.g., Solmon et al., 2004]. Global VOCs emissions by the vegetation are around $1150 \mathrm{TgC} / \mathrm{yr}$ [Guenther et al., 1995], corresponding to nearly $90 \%$ of global VOC emissions at the surface (including anthropogenic emissions). Among biogenic emissions, isoprene and terpenes are the most abundantly emitted species and forested areas are the most important sources. Once in the atmosphere, the oxidation of these VOCs increases or decreases the ozone formation, depending on $\mathrm{NO}_{\mathrm{x}}$ levels [Fehsenfeld et al., 1992; Thunis and Cuvelier, 2000; Atkinson and Arey, 2003].

[8] On the other hand, dry and wet depositions of atmospheric pollutants and aerosols are responsible for delivering to the biosphere atmospheric loads of various compounds: particles containing $\mathrm{SO}_{4}^{2}, \mathrm{NO}_{3}^{-}$and $\mathrm{NH}_{4}^{+}$that contribute to potential acidification and eutrophication of the ecosystems, natural or anthropogenic radioactive particles whose impact on the biosphere has to be estimated, base cations such as $\mathrm{Na}^{+}, \mathrm{K}^{+}, \mathrm{Ca}_{2}^{+}$and $\mathrm{Mg}_{2}^{+}$that influence the nutrient cycling in soil and ecosystems, and toxic heavy metals, such as $\mathrm{Pb}, \mathrm{Cd}$ and $\mathrm{Zn}$ [Ruijgrok et al., 1995; Petroff et al., 2008].

[9] Considering the $\mathrm{O}_{3}$, globally $600-1000 \mathrm{Tg} /$ year are removed from the troposphere via dry deposition [Ganzeveld et al., 2009]. The deposition of ozone to water surfaces is small compared to deposition to land [Ganzeveld and Lelieveld, 1995]: typically, the rate of dry deposition of ozone to the continent is nearly six times faster than the dry deposition rate of ozone to the ocean [Hauglustaine et al., 1994]. Therefore, obtaining an accurate prediction of ozone flux to the land is imperative not only in predicting ambient ozone concentrations, but also because of the biogeochemical consequences of ozone reactions on the land surface.

[10] According to Wesely [1989] the deposition velocity of a given species is described through an electrical resistance analogy, namely the transport of material to the surface is assumed to be controlled by three resistances: the aerodynamic resistance, the quasi-laminar layer resistance, and the surface resistance [Zhang et al., 2003]. Generally, the surface resistance is often the controlling resistance of deposition flux and, therefore, considerable effort has been devoted in the development of better parameterizations for incorporation in deposition models. The analytical description of surface resistance has been difficult since it involves physical, chemical and biological interactions of the pollutant with the deposition surfaces. Several models of different complexity have been developed to represent the dry deposition on vegetation covered surfaces [Baldocchi et al., 1987; Baldocchi et al., 1988; Wesely, 1989; Padro et al., 1991, 1992]. Models based on the big-leaf approach are most widely used [Hicks and Matt, 1988]. In these models, a single stomatal resistance, a single mesophyllic resistance, and a single cuticular resistance are used to characterize the canopy as a whole.

[11] Currently, in most of the chemical transport models (CTMs) the deposition modules are interlinked with land cover databases which provide information on the different resistance values through look-up tables. Modeling total deposition as a function of land-cover and climate is important to assess the stomatal flux to individual leaves and therefore to provide a good description of ozone loss processes. However, this approach does not provide any feedback between changes in vegetation functioning and subsequent impact on atmospheric chemistry, since, in most of CTMs, the effects of pollution on vegetation are not taken into account.

[12] Therefore, in order to better evaluate the regional exposure of ecosystems to air pollution as well as the feedbacks between vegetation and atmospheric chemistry, improved CTMs fully coupled with dynamic vegetation models are needed. Despite several studies having been performed in order to assess the impacts of pollution on vegetation [Adams et al., 1989; Ollinger et al., 1997; Martin et al., 2001; Nunn et al., 2002, 2005; Werner and Fabian, 2002; Fuhrer and Booker, 2003; Felzer et al., 2004, 2005; Karnosky et al., 2007; Matyssek et al., 2007, 2010a, 2010b; Ren et al., 2007; Sitch et al., 2007; Valkama et al., 2007], the vegetation-atmosphere feedbacks are still under investigated. Specifically, changes in biogenic emissions and dry deposition velocities owing to resulting impacts of ozone stress on vegetation have not yet been carried out.

[13] A previous study about the coupling between atmospheric chemistry and land surface has been performed by Anav et al. [2011]. They coupled the land surface model ORCHIDEE [Krinner et al., 2005] with the chemistry transport model CHIMERE [Bessagnet et al., 2004] in the Euro-Mediterranean area. In that experiment, the overall effect of tropospheric $\mathrm{O}_{3}$ on vegetation led to a reduction in yearly gross primary production (GPP) of about $22 \%$ and a reduction in LAI of $15 \%-20 \%$. Despite the severe ozone stress on vegetation and large changes in $\mathrm{O}_{3}$ precursors, they found only few and insignificant changes in tropospheric $\mathrm{O}_{3}$ concentration, except on few and isolated days during summer.

[14] In this study, starting from the model developed by Anav et al. [2011], we improve the coupling between the land surface model ORCHIDEE and the chemistry transport model CHIMERE considering the changes in ozone dry deposition owing to modifications in canopy due to the ozone stress on vegetation. Specifically, we attempt to assess how an improved canopy conductance parameterization affects $\mathrm{O}_{3}$ dry deposition velocities.

\section{ModelS Descriptions and Experiments}

\subsection{Chemical Transport Model}

[15] CHIMERE is a three-dimensional chemical transport model that, given a set of $\mathrm{NO}_{\mathrm{x}}, \mathrm{SO}_{\mathrm{x}}, \mathrm{NH}_{3}, \mathrm{PM}$, VOC and $\mathrm{CO}$ emissions, simulates gas-phase chemistry [Schmidt et al., 2001], aerosol formation, transport and deposition [Bessagnet et al., 2004; Vautard et al., 2005] at regional scales. In this study, CHIMERE is projected on a normal Mercator grid covering almost all Europe and North Africa (Figure 1), with a spatial resolution of $30 \mathrm{~km}$. The vertical grid contains 8 layers from the surface to $500 \mathrm{hPa}$. Hourly meteorological fields required by CHIMERE are provided by WRF model [Skamarock et al., 2005], while anthropogenic emissions are provided by EMEP [Vestreng, 2003]. Further information on WRF set-up and validation are given by Anav et al. [2010]. 


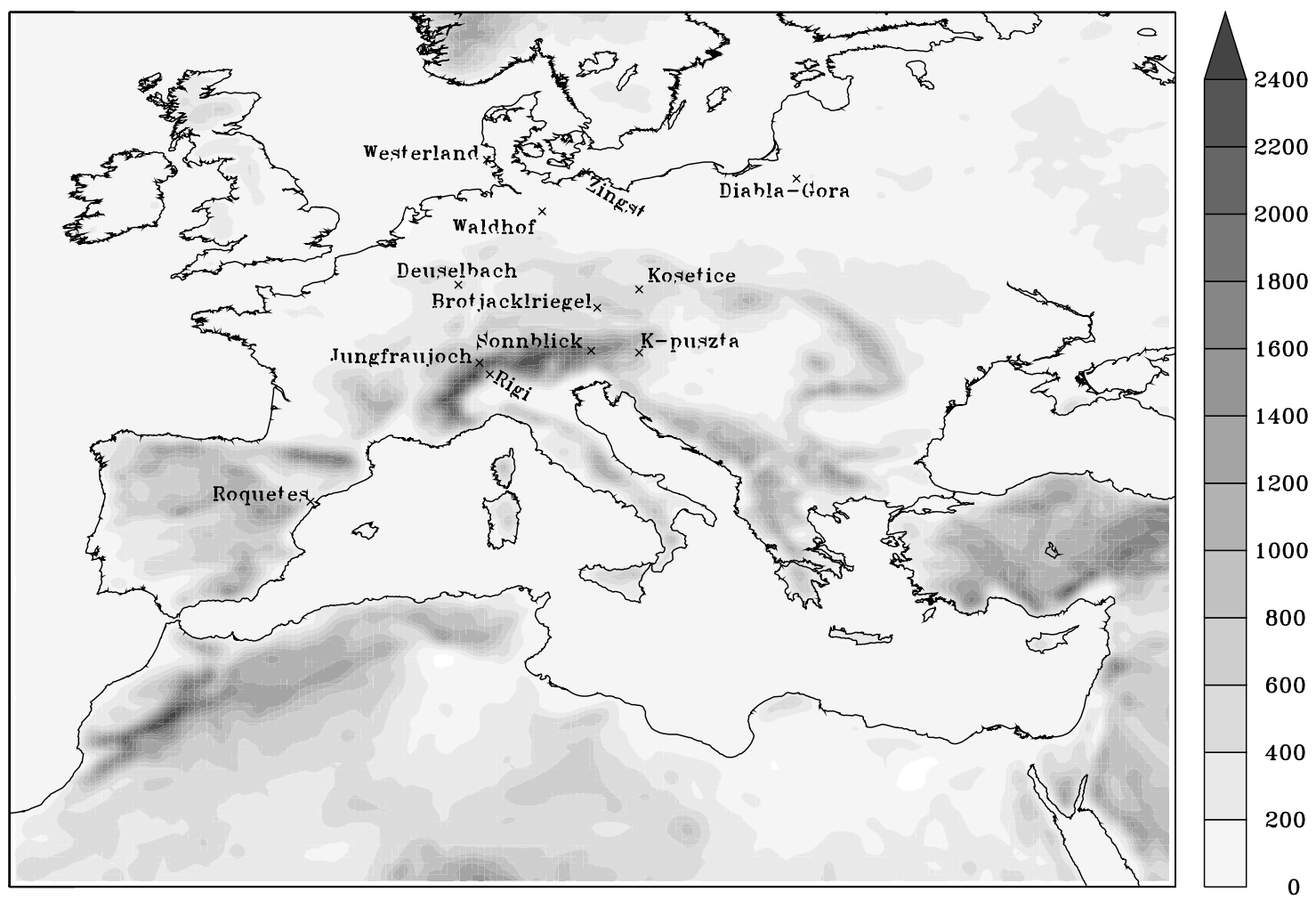

Figure 1. Model domain with the corresponding topography (unit=meters). The figure also shows the locations of the 12 sites used to validate the surface ozone concentration.

[16] Biogenic VOC emissions are computed through the MEGAN model [Guenther et al., 2006]. This model is based on the widely used parameterization by Guenther et al. [1995] with the flux F $\left(\mu \mathrm{g} \mathrm{m}^{-2} \mathrm{~h}^{-1}\right)$ of VOC $i$ :

$$
F_{i}=\varepsilon_{i} D \gamma_{i}
$$

modeled as a function of potential emission $\varepsilon_{\mathrm{i}}$, foliar density D specific for European vegetation [Simpson et al., 1999], and environmental correction factor $\gamma_{i}$ that accounts for temperature and radiation dependence.

[17] Dry deposition of a given gas species $i$, is parameterized as a downward flux $\left(F\right.$, molecules $\left.\mathrm{cm}^{-2} \mathrm{~s}^{-1}\right)$ :

$$
F_{i}=-v_{d, i} C_{i}
$$

out of the lowest model layer, with $C$ (molecules $\mathrm{cm}^{-3}$ ) being the concentration of species $i$ at some reference height above the surface.According to Wesely [1989] the deposition velocity $\left(v_{d, i} \mathrm{~cm} \mathrm{~s}^{-1}\right)$ is described through an electrical resistance anomaly, namely the transport of material to the surface is assumed to be controlled by three different resistances in series: the aerodynamic resistance $\left(R_{a}\right.$, is the same for all gasses), the quasi-laminar layer resistance $\left(R_{b, i}\right)$, and the surface resistance $\left(R_{c, i}\right)$. The total resistance $\left(R_{t, I}, \mathrm{~s} \mathrm{~cm}^{-1}\right)$ to deposition of a gaseous species is therefore the sum of these three individual resistances and is, by definition, the inverse of the deposition velocity:

$$
v_{d, i}=\frac{1}{R_{a}+R_{b, i}+R_{c, i}} .
$$

In this study we focus only on the $R_{c}$ term since it contains the feedback between ORCHIDEE and CHIMERE, while further details on the other terms are given by Seinfeld and Pandis [2006].

[18] In CHIMERE the formulation of surface resistance follows the methodology developed by Wesely [1989] and Erisman et al. [1994]. It depends on the surface type and gas properties, i.e., it is regulated by the stomatal uptake, which has a specific biological significance, as well as on external plant surfaces like the soil underlying the vegetation that must be considered as a potential sink for ozone. Since in the coupled version we only have modified the terms regulating the stomatal uptake, leaving unchanged the parameterizations of the other terms, below we only describe the stomatal uptake, while details on other deposition pathways can be found in Seinfeld and Pandis [2006]. It should also be noted, however, that several studies attribute a major part of the total annual ozone deposition to non-stomatal pathways [e.g., Fowler et al., 2001; Mikkelsen et al., 2004; Altimir et al., 2006; Stella et al., 2011].

[19] Considering the contribution of vegetation to the overall surface resistance, it depends on a combination of cuticular (leaf skin) and stomatal (leaf pores) resistances acting in parallel. The cuticular resistance is generally greater than the stomatal resistance and, therefore, dry deposition occurs mostly through the stomata [Bessagnet et al., 2010]. The stomatal resistance consists of two sequential resistances: a stomatal pore resistance (uptake of the chemical species via the pore orifice) and a mesophyllic resistance (transfer of chemical species at leaf tissue interface). The stomatal resistance depends on solar radiation, temperature, 


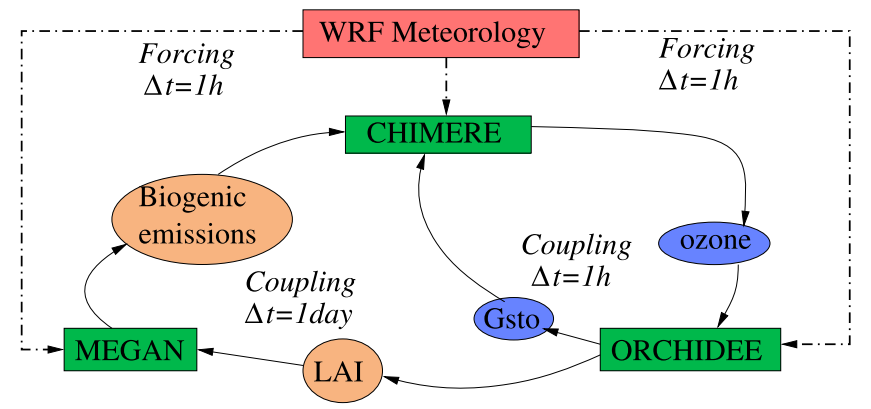

Figure 2. Flowchart of the CHIMERE-ORCHIDEE coupled model. The green boxes represent different models, the blue boxes highlight the variables exchanged between CHIMERE and ORCHIDEE at hourly time step, and the dark pink boxes show the daily coupling between CHIMERE and ORCHIDEE through the biogenic emission model MEGAN. Both CHIMERE and ORCHIDEE are forced by hourly data from WRF model.

soil water availability, and molecular diffusivity. The mesophyllic resistance depends on the water solubility of the compound and its reactivity [Wesely, 1989; Erisman et al., 1994; Seinfeld and Pandis, 2006].

[20] Two types of algorithms have been widely used to predict stomatal conductance ( $g_{\text {sto }}$, where conductance is the reciprocal of resistance). The first is the multiplicative algorithm developed by Jarvis [1976] and further developed specifically to model ozone uptake by plants [Emberson et al., 2000; Grünhage et al., 2000]. This algorithm calculates $g_{\text {sto }}$ as a function of phenology, photosynthetic photon flux density (PPFD), air temperature, vapor pressure deficit (VPD) and soil moisture related parameters. The second type of algorithm is the semi-mechanistic model developed by Ball et al. [1987]. It is based on the evidence of a close relationship between $g_{\text {sto }}$ and net photosynthetic rate $\left(A_{n}\right)$, which provides the link between the exchange of gases (e.g., $\mathrm{CO}_{2}, \mathrm{H}_{2} \mathrm{O}, \mathrm{O}_{3}$ ) and the prevailing climatic conditions. The Ball algorithm computes $g_{\text {sto }}$ as a function of $A_{n},\left[\mathrm{CO}_{2}\right]$ and relative humidity. Stomatal responses to $\mathrm{CO}_{2}, \mathrm{PPFD}$, and temperature are included by means of photosynthetic model. In contrast with the multiplicative algorithm, these responses act synergistically [Büker et al., 2007].

[21] To account for stomatal conductance CHIMERE uses the parameterization of Emberson et al. [2000] developed from the multiplicative algorithm of Jarvis [1976]. According to this formulation, the stomatal conductance is calculated for different land cover types within a grid cell as a function of the kind of vegetation, phenology, and environmental conditions, since these latter are the factors considered most important in determining stomatal aperture:

$$
\mathrm{g}_{\text {sto }}=\mathrm{g}_{\max } \mathrm{g}_{\mathrm{pot}} \max \left\{\mathrm{g}_{\min },\left(\mathrm{g}_{\text {light }} \mathrm{g}_{\text {temp }} \mathrm{g}_{\mathrm{VPD}} \mathrm{g}_{\mathrm{SWP}}\right)\right\} / 41000,
$$

where $g_{\max }$ is the species-specific maximum stomatal conductance to ozone $\left(\mathrm{mmol} \mathrm{O}_{3} \mathrm{~m}^{-2} \mathrm{~s}^{-1}\right)$ expressed on a total leaf surface area, $g_{\min }$ is the minimum daytime stomatal conductance, and 41000 is the factor used to convert from $\mathrm{mmol} \mathrm{m} \mathrm{s}^{-1} \mathrm{~s}^{-1}$ to $\mathrm{m} \mathrm{s}^{-1}$. The variables $g_{\text {pot }}, g_{\text {light }}, g_{\text {temp }}, g_{V P D}$ and $g_{S W P}$ are all expressed in relative terms (i.e., they take a value between 0 and 1) as a proportion of $g_{\max }$ and they represent the response of stomatal conductance to phenology $\left(g_{\text {pot }}\right)$, light $\left(g_{\text {light }}\right)$, leaf temperature $\left(g_{\text {temp }}\right)$, vapor pressure deficit $\left(g_{V P D}\right)$, and soil water status $\left(g_{S W P}\right)$. Further details on the parameterization of these latter variables are given by Emberson et al. [2000].

\subsection{Land Surface Model}

[22] The land-surface model ORCHIDEE (ORganizing Carbon and Hydrology In Dynamic EcosystEms) is a SVAT model coupled to a biogeochemistry and a dynamic biogeography model [Krinner et al., 2005]. ORCHIDEE simulates the fast feedback occurring between vegetated land surface and atmosphere, the terrestrial carbon cycle, and also changes in vegetation composition and distribution in response to climate change.

[23] ORCHIDEE is based on three different modules [Krinner et al., 2005]. The first module, called SECHIBA [Ducoudré et al., 1993], describes the fast processes such as exchanges of energy and water between atmosphere and biosphere, and the soil water budget.

[24] The phenology and carbon dynamics of the terrestrial biosphere are simulated by STOMATE (Saclay Toulouse Orsay Model for the Analysis of Terrestrial Ecosystems) model [Krinner et al., 2005]. STOMATE simulates, with a daily time step, processes such as photosynthesis, carbon allocation, litter decomposition, soil carbon dynamics, maintenance and growth respiration, and phenology. Finally, long-term processes (yearly time step), including vegetation dynamics, fire, sapling establishment, light competition, and tree mortality are simulated according to the global vegetation model LPJ [Sitch et al., 2003].

[25] Meteorological data used to drive ORCHIDEE include temperature, precipitation, specific humidity, wind speed, pressure, short wave and long wave incoming radiation. In the present study a regional version of ORCHIDEE [Anav et al., 2010], projected on the same CHIMERE grid (Figure 1), is forced by hourly meteorological forcing provided by WRF model [Skamarock et al., 2005].

[26] In ORCHIDEE the land surface is described as a mosaic of twelve plant functional types (PFTs) and bare soil. The definition of PFT is based on ecological parameters such as plant physiognomy (tree or grass), leaves (needleleaf or broadleaf), phenology (evergreen, summergreen or raingreen) and photosynthesis type for crops and grasses (C3 or 


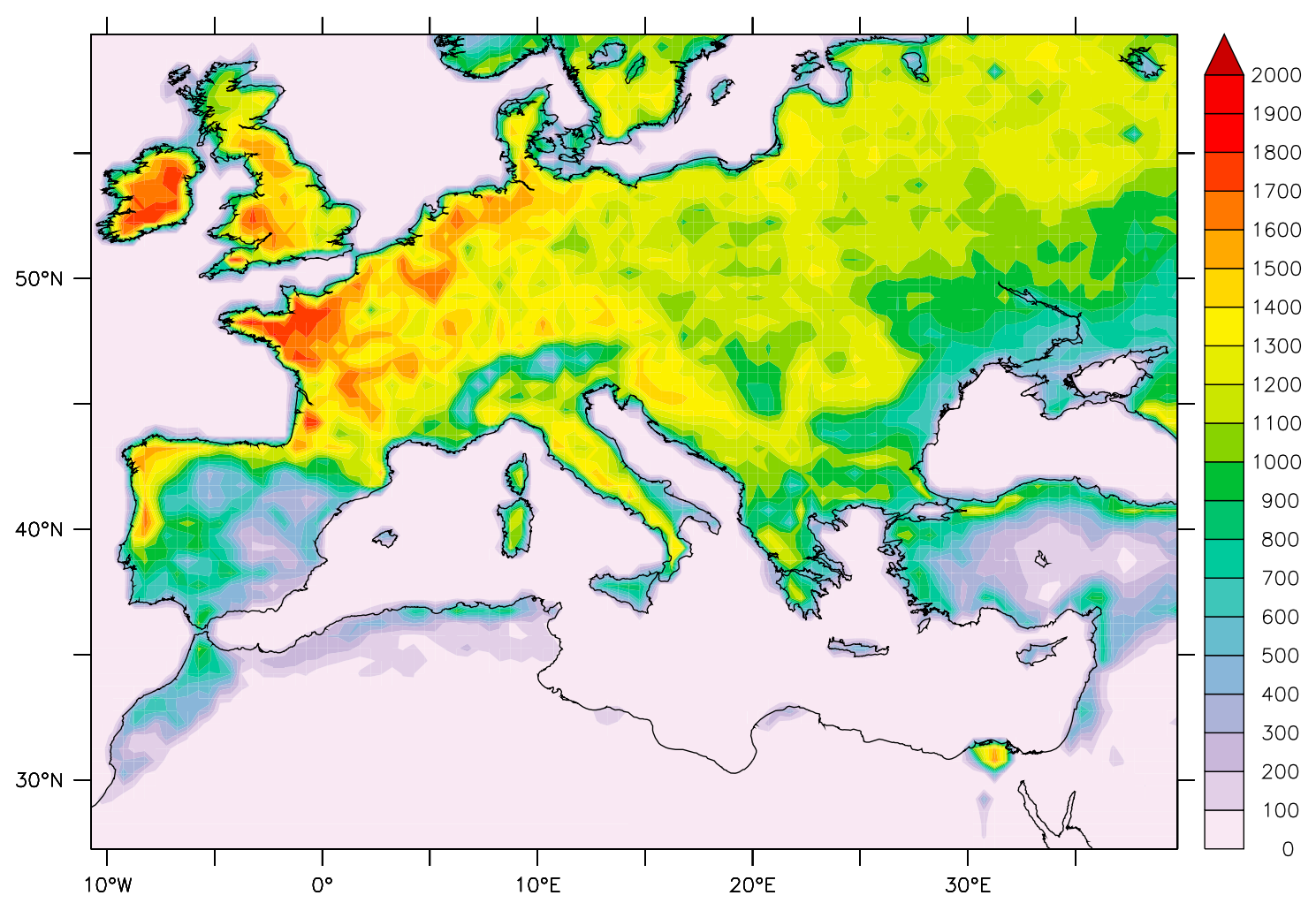

ORCHIDEE GPP

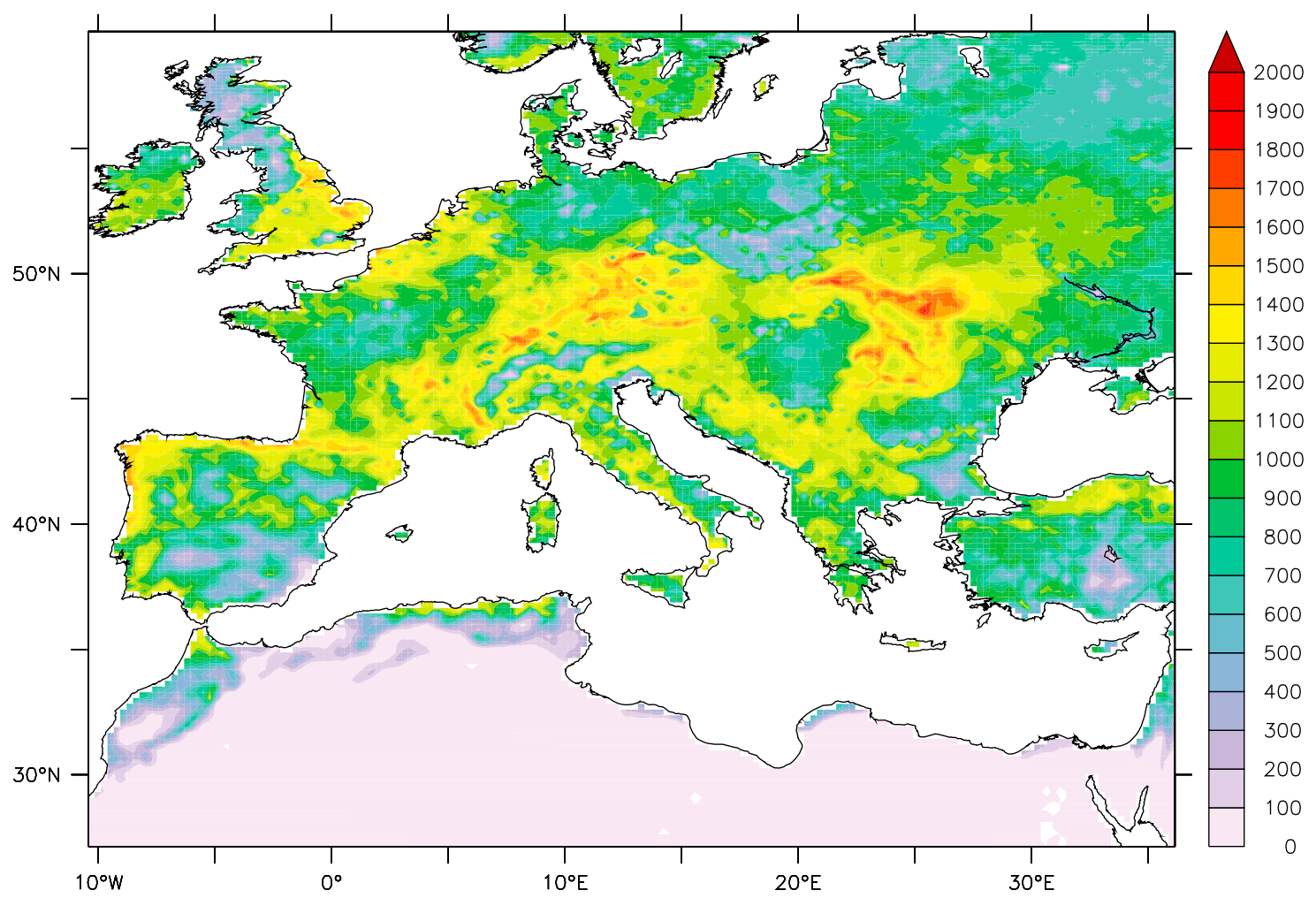

Figure 3. Comparison of annual GPP as simulated by ORCHIDEE in the coupled model and the reference GPP (MTE-GPP). 
ANNUAL

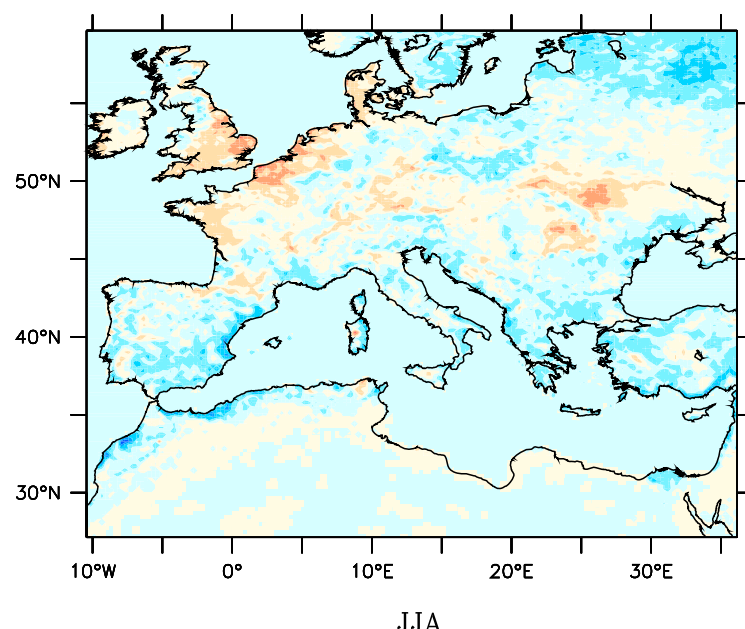

JJA

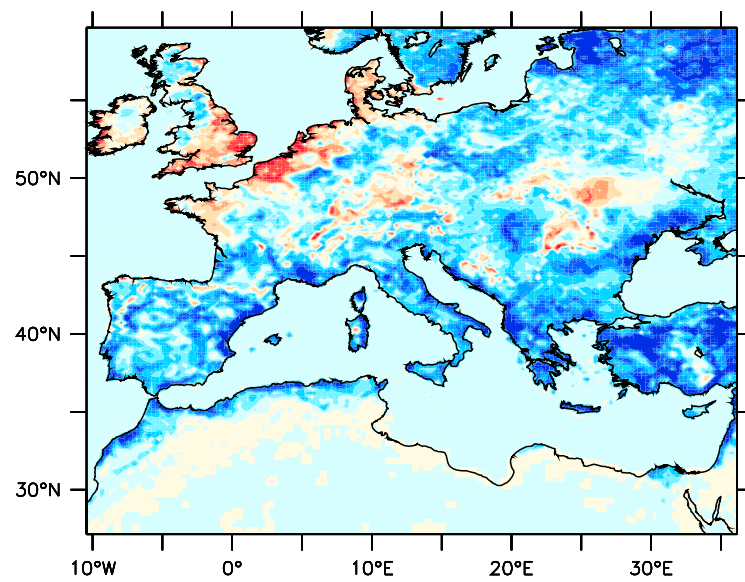

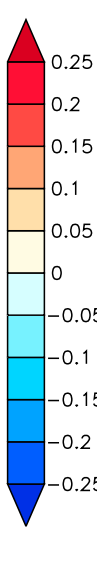

0.25
0.2
0.15

$50^{\circ} \mathrm{N}$

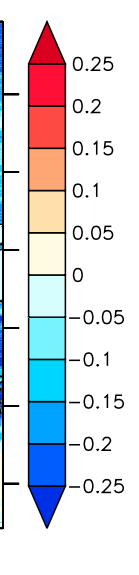

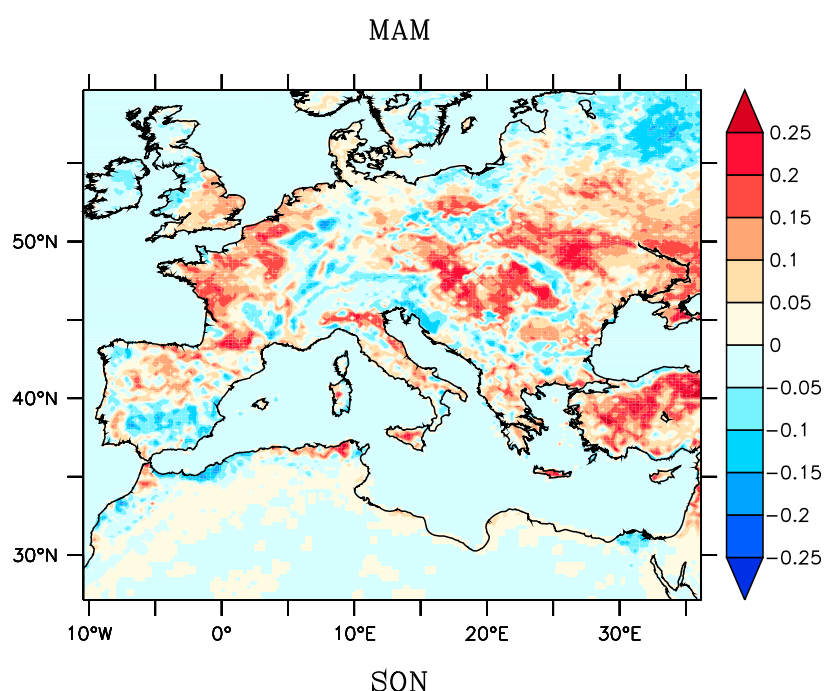

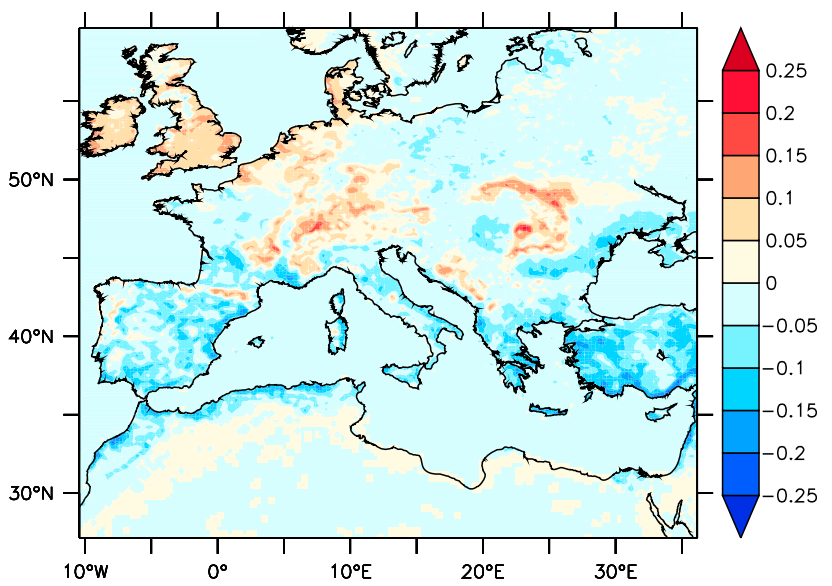

Figure 4. Mean annual and seasonal anomalies (CPL-CTL) in canopy conductance (unit $=\mathrm{cm} / \mathrm{s}$ ). The canopy conductance has been computed averaging over all the PFTs.

C4). Relevant biophysical and biogeochemical parameters are prescribed for each PFT [Krinner et al., 2005].

[27] The PFT distribution can be either prescribed from an input inventory (static mode, LPJ deactivated), or entirely simulated by the model depending on climate conditions (dynamic mode, LPJ activated). The fraction of grid space covered by agricultural croplands is always prescribed, so that crop extent is not affected by dynamic vegetation change.

[28] In this work the vegetation distribution is prescribed, while plant phenology and the carbon cycle are explicitly simulated. It is noteworthy that atmospheric $\mathrm{CO}_{2}$ variations strongly affect photosynthesis; for this reason, we prescribed the atmospheric $\mathrm{CO}_{2}$ concentration at 2002 levels (373 ppm).

\subsection{Coupling Between CHIMERE and ORCHIDEE}

[29] CHIMERE and ORCHIDEE are online coupled via canopy conductance, LAI, and surface ozone concentration, as described in Figure 2. In order to compute the impact of ozone on photosynthesis and the consequent change in dry deposition, the canopy conductance and surface ozone concentration are exchanged by the models at hourly time step, while the LAI provided by ORCHIDEE is used at daily time step by the MEGAN model (Figure 2). Additionally, in the coupled version, instead of using the multiplicative algorithm developed by Jarvis [1976] to account for canopy conductance, CHIMERE uses the canopy conductance directly computed by ORCHIDEE.

[30] In ORCHIDEE the stomatal conductance parameterization follows the semi-mechanistic model of Ball et al. [1987]. This algorithm has become increasingly popular in combination with photosynthesis models [e.g., Farquhar et al., 1980] for plant growth simulations. Since this algorithm offers the capability to model ozone-induced changes of photosynthetic rate, it is of interest for ozone impact assessment [e.g., Weinstein et al., 1998]. Therefore, it is well suited to study the feedback between ozone-photosynthesis/ canopy conductance-atmospheric chemistry.

[31] According to the parameterization of Ball et al. [1987] $g_{\text {sto }}$ dependents on $\mathrm{CO}_{2}$ concentration $\left(C_{s}\right)$ and relative humidity $\left(h_{s}\right)$ at the leaf surface, and temperature and radiation through net photosynthesis $\left(A_{n}\right)$ :

$$
\mathrm{g}_{\text {sto }}=\mathrm{g}_{0}+\frac{\mathrm{kA}_{\mathrm{n}} \mathrm{h}_{\mathrm{s}}}{\mathrm{C}_{\mathrm{s}}}
$$



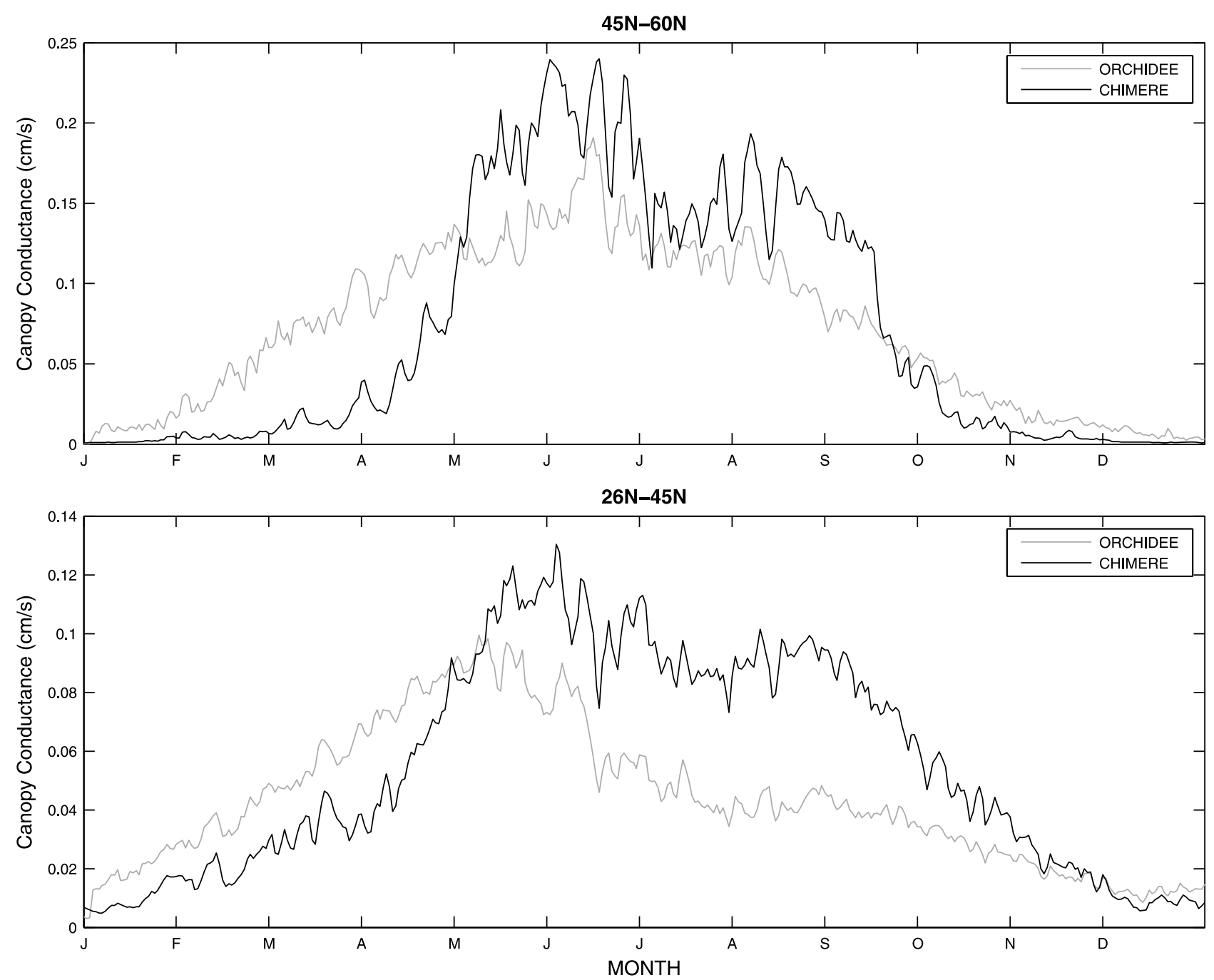

Figure 5. Time series of daily canopy conductance as simulated in CHIMERE CPL and CTL simulations. To highlight the latitudinal effect on the results, two sub-domains are defined and the time series have been spatially averaged over these domains: a southern domain with all values below $45^{\circ} \mathrm{N}$ and a northern domain with all values above $45^{\circ} \mathrm{N}$. Shown are averages over all the PFTs.

where $g_{0}$ is the residual stomatal conductance when $A_{n}$ approaches zero, $k$ is the slope of the relationship between $g_{\text {sto }}$ and $\left(A_{n}{ }^{*} h_{s}\right) / C_{s}$ (the Ball index). For a plant under well watered conditions $k$ is constant; thus the Ball model is a simple linear relationship between $g_{\text {sto }}$ and $\left(A_{n}{ }^{*} h_{s}\right) / C_{s}$ [Gutschick and Simonneau, 2002]. However, under soil water deficits $k$ has been shown to vary, and the relationship between $g_{\text {sto }}$ and the Ball index becomes curvilinear [Sala and Tenhunen, 1996].

[32] Despite the accuracy of the Farquhar/Ball-Berry physiological model in many situations, conditions related to atmospheric pollutants that decrease the stomatal conductance (and hence the carboxylation) cannot be accurately predicted without a further modification of this parameterization. For such reason, we modified ORCHIDEE including the effects of ozone on photosynthesis. The parameterization of ozone impact on GPP is based on Felzer et al. [2004]; according to this formulation $\mathrm{O}_{3}$ is supposed to impact photosynthesis through its concentration in the chloroplast, this latter depending on $\mathrm{O}_{3}$ atmospheric concentration and stomatal conductance. Further details on the algorithms and the ORCHIDEE modifications are described by Anav et al. [2011].

[33] Since the net photosynthesis $\left(A_{n}\right)$ depends on ozone, all the equations show a close relationship between ozone, canopy conductance and photosynthesis. Besides, changes in photosynthesis lead to a modification in the amount of carbon stored into the biomass and therefore to a change of LAI that may, in turn, affects biogenic emissions and dry deposition. Although several studies report a large reduction in GPP due the $\mathrm{O}_{3}$ stress that translates in significant changes in the energy partition in the planetary boundary layer (PBL), to date, the Earth System Models used for the next IPCC report (AR5) do not include these feedbacks.

[34] In the original CHIMERE version, the leaf area index database is provided as a monthly mean product derived from MODIS observations, referred to base year 2000 [Bessagnet et al., 2008]. In the coupled version, indeed, CHIMERE uses the daily LAI values directly computed by ORCHIDEE to account for biogenic emissions (Figure 2). 

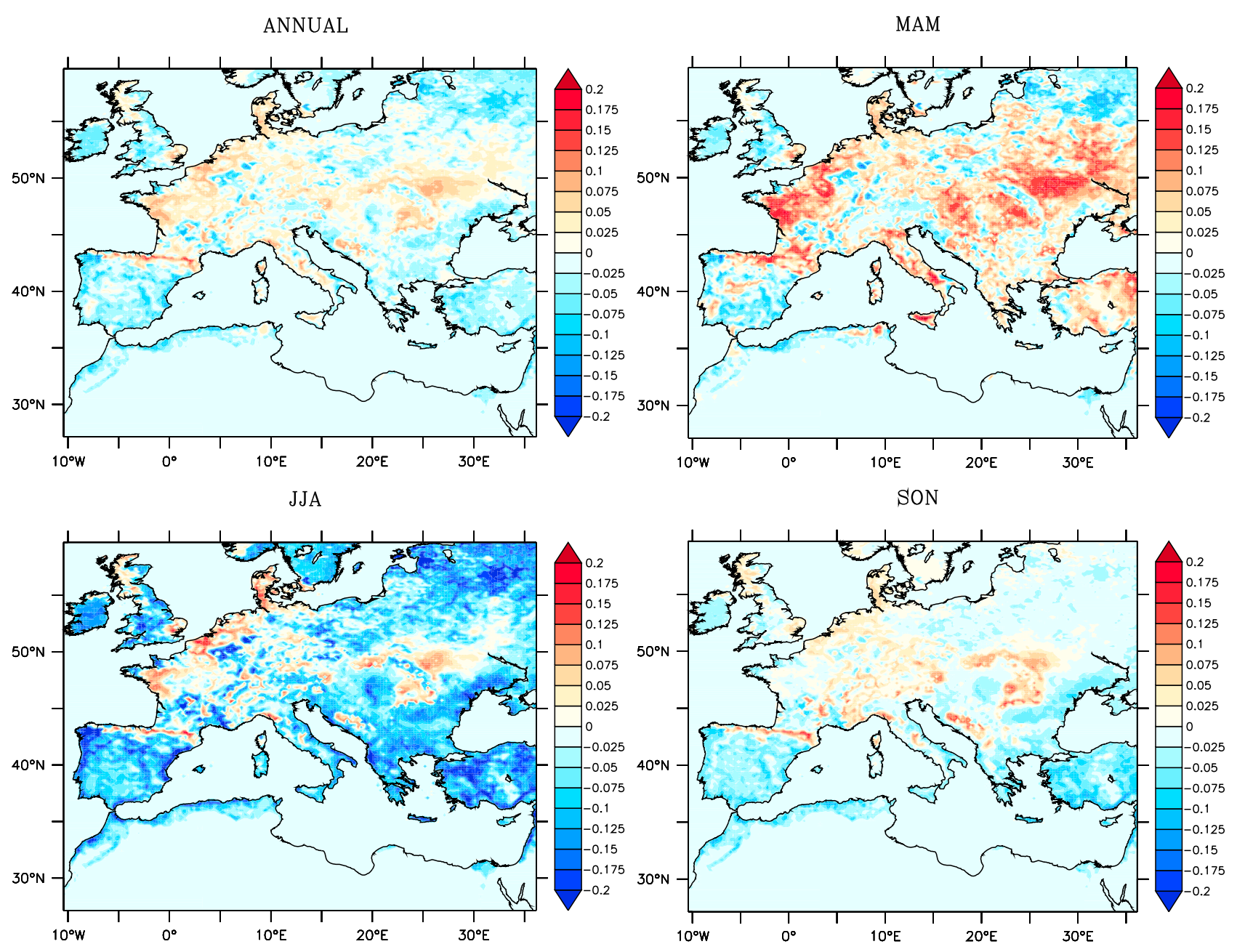

Figure 6. Mean annual and seasonal anomalies (CPL-CTL) in dry deposition velocity (units $=\mathrm{cm} / \mathrm{s}$ ).

[35] For each model we carried out two different simulations for the full year 2002, one uncoupled simulation in which both CHIMERE and ORCHIDEE have been run in their original configuration (in ORCHIDEE was not considered the impact of ozone on vegetation, while CHIMERE uses the original canopy conductance formulation and LAI data set to account for dry deposition and BVOCs emissions, respectively), and one coupled simulation in which the two models exchange ozone-canopy conductance-LAI, as described in Figure 2.

[36] The difference between the coupled and uncoupled simulations allows a quantification of the impact of ozone on vegetation and the consequent changes in atmospheric chemistry and in $\mathrm{O}_{3}$ concentration.

\section{Results}

\subsection{Impact of Ozone on Vegetation}

[37] The overall impact of ozone on vegetation, computed comparing the coupled simulation with the control run (this latter does not takes into account any negative effect of ozone on vegetation), shows that the mean GPP reduction is about $200 \mathrm{gC} \mathrm{m}^{2} \mathrm{y}^{-1}$, that roughly corresponds to the $23 \%$ of the yearly value. Figure 3 shows the validation of GPP, namely the comparison of the spatial distribution of GPP simulated by the coupled model against a reference GPP [Jung et al., 2009, 2011]. As reference GPP, here we use estimates derived from the upscaling of data from the FLUXNET network of eddy covariance towers [Beer et al., 2010]. The global FLUXNET upscaling uses data oriented diagnostic models trained with eddy covariance flux data to provide empirically derived, spatially gridded fluxes. In this study, we use the global FLUXNET upscaling of GPP based on the model tree ensembles (MTE) approach, described by Jung et al. [2009, 2011]. Looking at Figure 3 ORCHIDEE generally well captures the spatial distribution of the GPP, despite a relevant underestimation over west France, Ireland and Southern England, and an overestimation around the Carpathian mountains.

[38] The reduction in carbon assimilation leads also to a less amount of leaf biomass, specifically we found a decrease of LAI of about $16 \%$.

[39] The ozone stress on GPP, and the resulting LAI decrease, are of the same magnitude of results found by Anav et al. [2011], consequently for a further and detailed description of the process involved in the GPP and LAI reduction, as well as for the ORCHIDEE validation over specific sites, we will refer to this paper, while in the next section we describe the changes in dry deposition owing to the improved canopy conductance parameterization. 

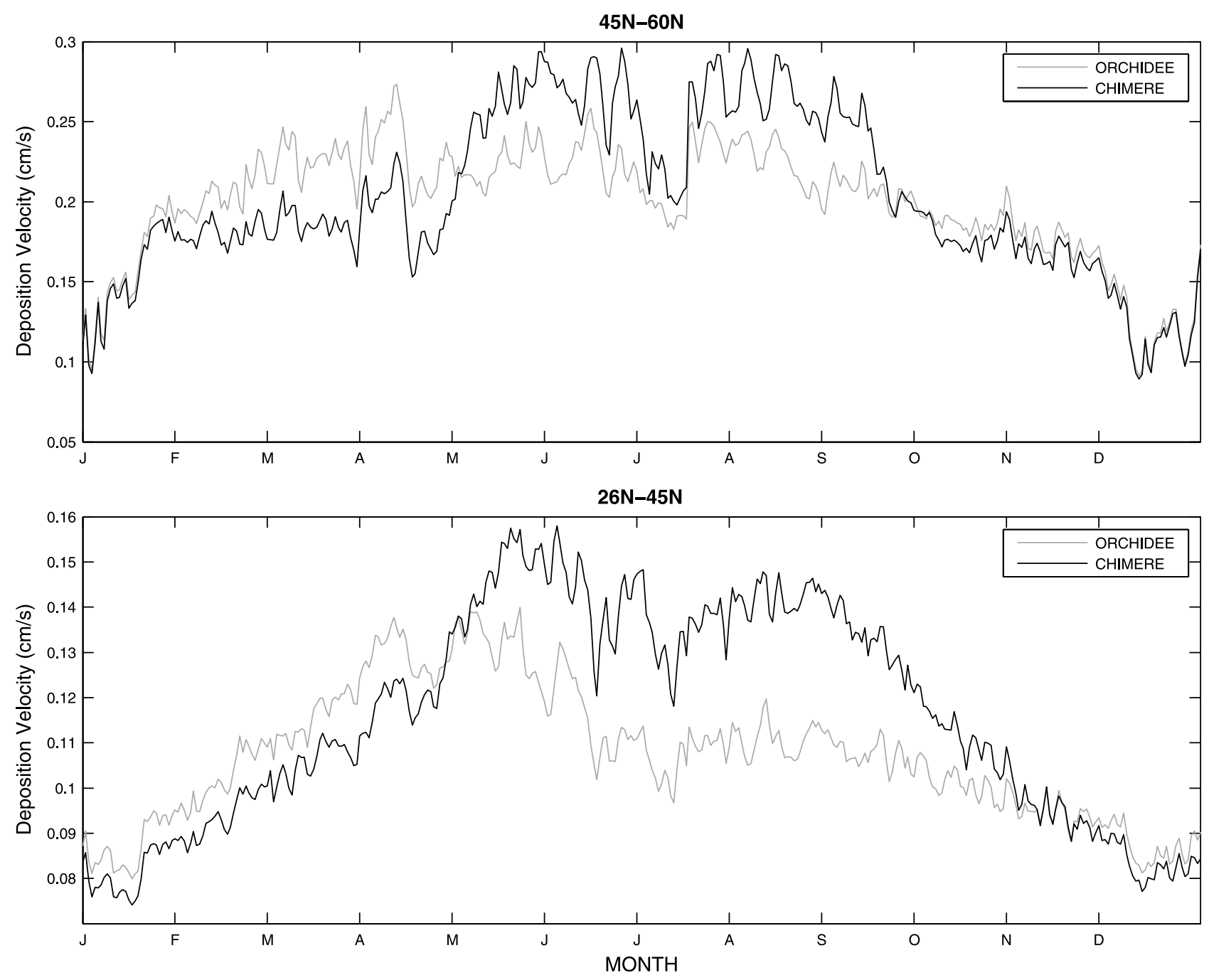

Figure 7. Time series of daily dry deposition velocities as simulated by CPL and CTL.

\subsection{Changes in Dry Deposition}

[40] Notwithstanding the low sensitivity of CHIMERE to BVOCs emissions [Curci et al., 2009; Anav et al., 2011], we expect a large impact on CHIMERE-simulated $\mathrm{O}_{3}$ through different canopy conductance parameterizations. As already described before, for the stomatal conductance parameterization ORCHIDEE follows the semi-mechanistic model of Ball et al. [1987], while CHIMERE uses the multiplicative algorithm developed by Jarvis [1976].

[41] Looking at the spatial canopy conductance anomalies (Figure 4) it is remarkable that the CHIMERE coupled simulation (henceforth CPL) is consistently higher than the control run (henceforth CTL) during spring (MAM) in almost all central-Eastern Europe and in the Mediterranean basin, while it is systematically lower almost everywhere (except in the South of England and Northern coasts of France) during summer (JJA). The mean annual value is affected by this pattern, namely the canopy conductance of CPL is higher than CTL in North of France, South of England and central-Eastern Europe, while it is systematically lower in the entire Mediterranean region.

[42] These results could be explained with the better parameterizations of land surface processes in ORCHIDEE that allow to Mediterranean forests to be water-limited during the dry season (i.e., JJA) [Hoff et al., 2002; Keenan et al., 2009]. Namely, since canopy conductance in ORCHIDEE is strictly related to net photosynthesis (equation (5)), and this latter variable decreases during summer in Mediterranean regions due to the low amount of water available in the soil [Hoff et al., 2002; Galmés et al., 2007; Granier et al., 2007; Allard et al., 2008; Keenan et al., 2009], we partially expected this pattern.

[43] In order to point out the seasonal changes in canopy conductance, in Figure 5 we plot the domain-averaged time series for both CTL and CPL; in addition, for a better representation of processes taking place in Mediterranean regions, we split the domain in two different sub-domains. The Mediterranean sub-domain falls between $26^{\circ} \mathrm{N}$ and $45^{\circ} \mathrm{N}$, while the Central-Europe domain falls between $45^{\circ} \mathrm{N}$ and $60^{\circ} \mathrm{N}$.

[44] Generally, the two time series show the same temporal evolution in the Mediterranean sub-domain, characterized by low values during winter and fall, and an increase in plant activity in spring, followed then by a decrease in summer (mid June) related to the severe water stress that vegetation suffers during the dry season in the Mediterranean basin 
CHIMERE Canopy Conductance $(\mathrm{cm} / \mathrm{s})$

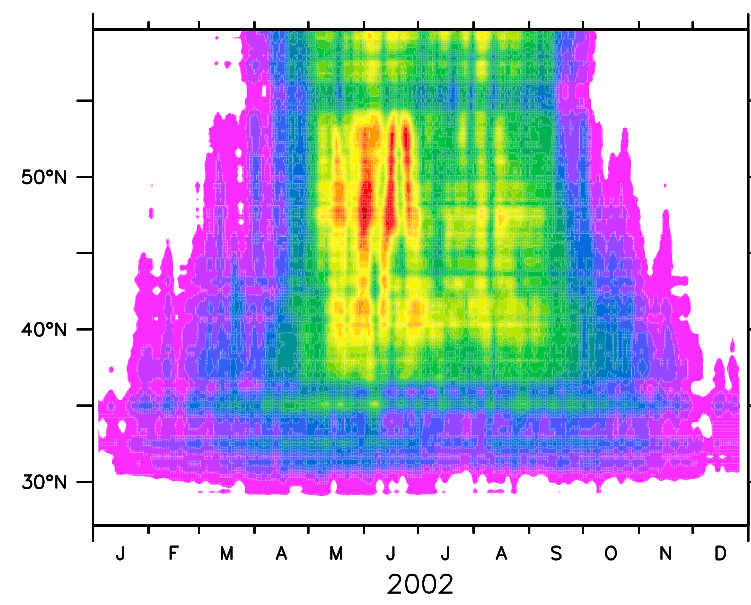

CTL Dry Deposition Velocity $(\mathrm{cm} / \mathrm{s})$

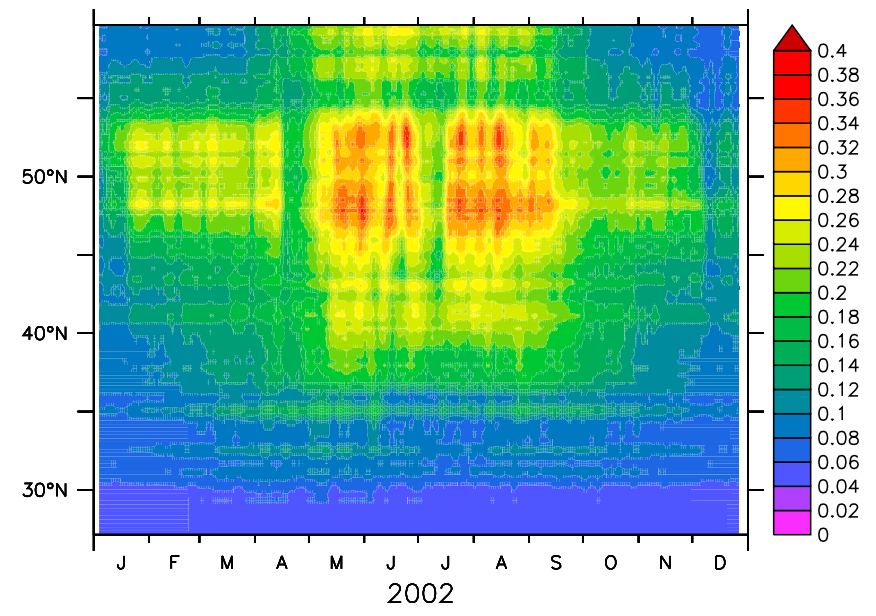

ORCHIDEE Canopy Conductance $(\mathrm{cm} / \mathrm{s})$

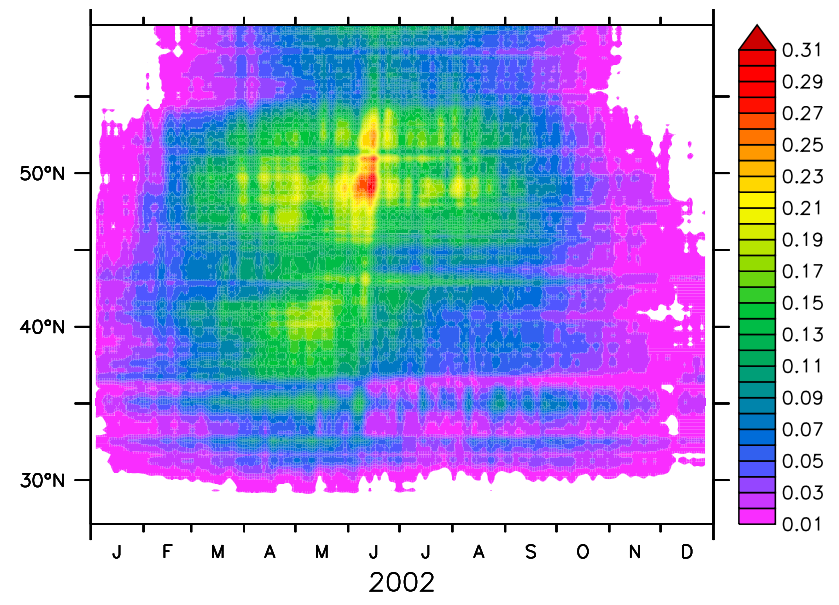

CPL Dry Deposition Velocity $(\mathrm{cm} / \mathrm{s})$

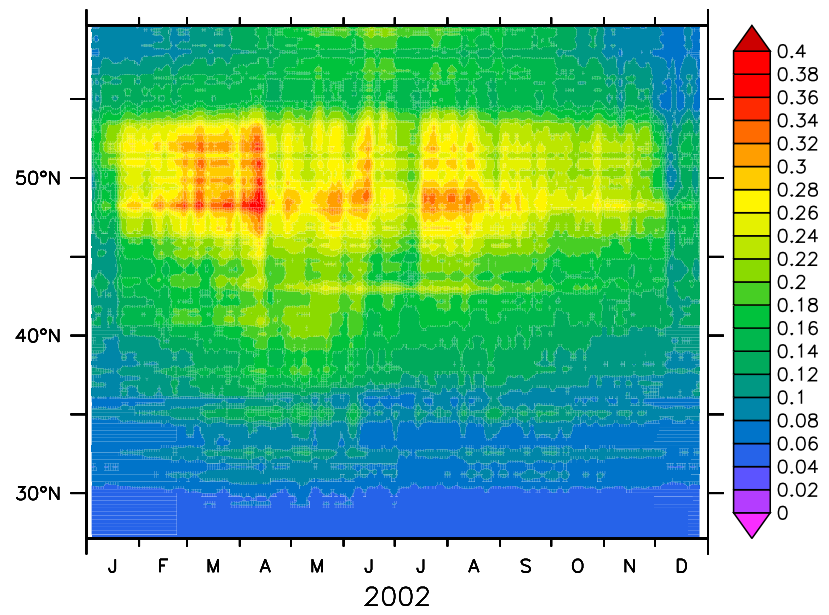

Figure 8. Latitude-time plots of mean daily canopy conductance as simulated by (a) CHIMERE and (b) ORCHIDEE, and mean daily dry deposition velocity simulated by CHIMERE in the (c) control and (d) coupled runs. Data have been averaged between $10.6^{\circ} \mathrm{W}$ and $36.3^{\circ} \mathrm{E}$; and to avoid the daily noise, a 1-week smoothing has been applied.

[e.g., Galmés et al., 2007; Keenan et al., 2009]. Indeed, the time series in central Europe show relevant differences between the control and coupled simulations and from this figure we can draw two important considerations that will affect the next discussion of results. First, during winter the canopy conductance in CTL is systematically lower than that from CPL. Since the canopy conductance in CTL is close to zero until March and it starts rising significantly only from April, this suggests that CTL does not correctly reproduce the winter and early spring activity of evergreen forests, grassland and cropland. In fact, unlike summer-green forests, evergreen forests and some crops and grassland have a photosynthetic activity year-round, namely these kinds of vegetations are able to absorb the atmospheric $\mathrm{CO}_{2}$ during all the year. Therefore the canopy conductance for these vegetation types would be expected to be greater than zero also during winter, as correctly simulated by CPL.

[45] Second, as the growing season starts (April), CTL shows an abrupt increase in canopy conductance likely related to the leaf-out of summer-green forests and the enhanced activity of croplands and grasslands, and this remains larger than CPL during all the summer and the early fall (till October). The sharp increase in canopy conductance suggests that the fraction of evergreen forests or crops might be misrepresented in the CTL simulation, and the fractional coverage of deciduous forests might be higher than observed. This is then confirmed by the abrupt decrease in canopy conductance taking place in October, and it is likely related to the end of photosynthetic activity of deciduous forests and annual agricultural crops. In addition, also the large impact of ozone on photosynthesis during late spring and summer could explain the large discrepancy between the seasonal time series of canopy conductance. Specifically, in the parameterization of Ball et al. [1987] used by ORCHIDEE, $g_{\text {sto }}$ depends on net photosynthesis (see equation (5)), and this latter is strongly lowered by the negative effect of ozone [Anav et al., 2011].

[46] The above differences in canopy conductance first of all affect the dry deposition velocities through the modification of the surface resistance term $R_{c}$ (see equation (3)). Looking at the seasonal spatial variability of deposition velocity this basically reflects the canopy conductance 

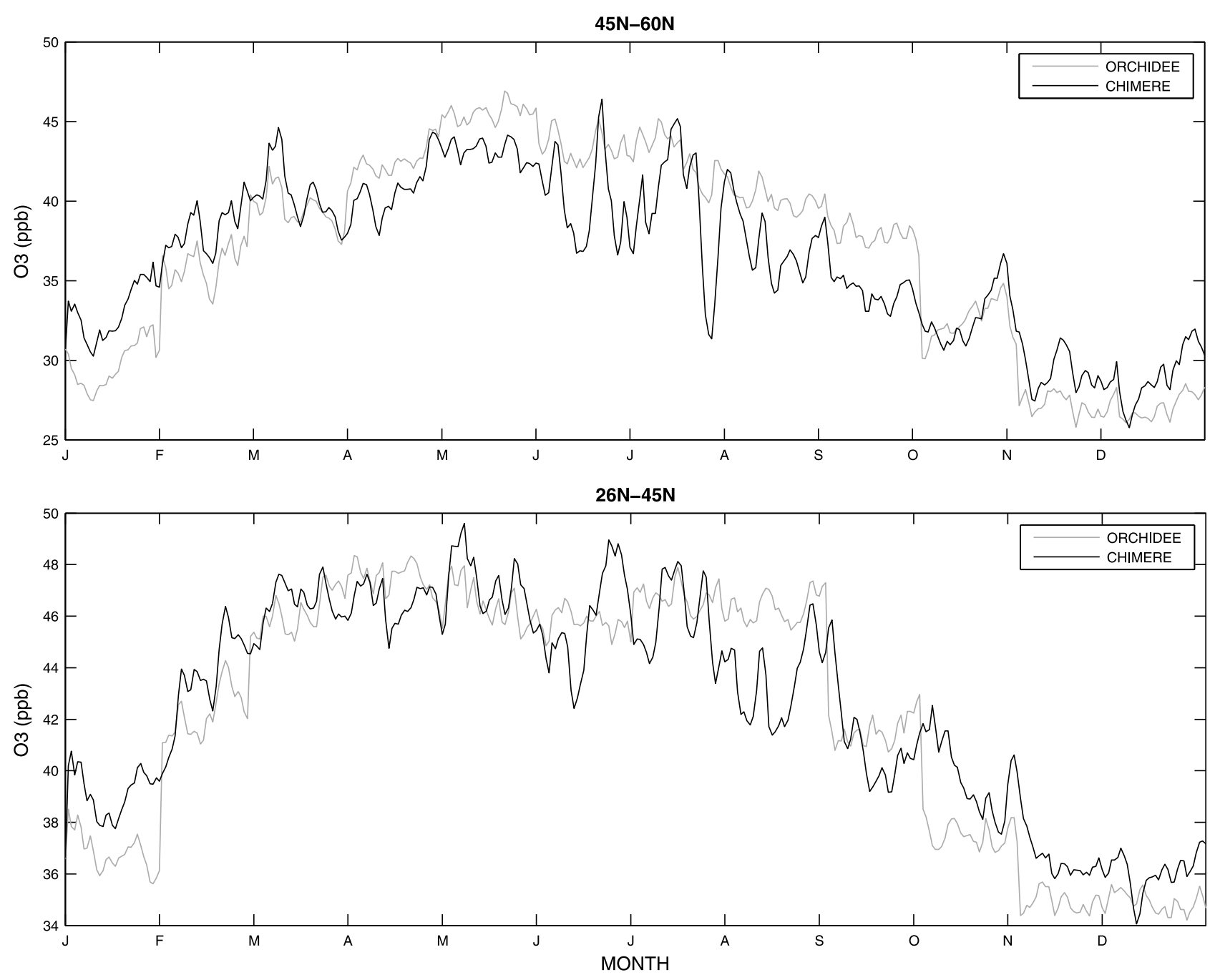

Figure 9. Time series of daily surface ozone concentration as simulated by CPL and CTL.

anomaly, namely the deposition velocity is largely greater in CPL in all central Europe during MAM and it is generally lower around the whole Mediterranean region and parts of Central-North Europe during summer (Figure 6). The yearly mean, indeed, shows that the deposition velocity is greater in CPL in Atlantic coasts of France, in the Pyrenees, and around the Carpathian mountains, and is generally lower around all Mediterranean region, while in Southern England it does not show the same strong pattern that we found in CPL for the canopy conductance.

[47] In Figure 7 we compare the seasonal cycle of dry deposition velocities from CHIMERE control and coupled simulations. According to Figure 5, during winter and spring the dry deposition velocities are greater in the coupled simulation because of larger canopy conductance found in ORCHIDEE. Specifically, to a higher canopy conductance corresponds a higher amount of ozone that enters the leaves and therefore is removed in the lowest layer of the model. In addition, although the canopy conductance in CTL is close to zero during winter, the CTL dry deposition velocity is overlapped to CPL from November to January, at least in Central-Europe sub-domain. This suggests that during the winter months (i.e., for low canopy conductance) the individual resistance $\mathrm{R}_{\mathrm{c}}$ plays a pivotal role controlling the deposition velocity through a strong limitation to deposition, and the high surface resistance values explain why CTL and CPL are overlapped during cold months $\left(R_{a}\right.$ and $R_{b}$ terms are the same between the control and coupled simulations).

[48] From the late spring the deposition velocity in CTL becomes larger than CPL (Figure 7) in both the subdomains, although this is much more evident in the Mediterranean basin; this is caused by the abrupt increase of canopy conductance in CTL (Figure 5). Finally from the end of the summer until the end of the year the deposition velocities do not show any relevant difference.

[49] In addition, we would highlight that the time series representing the daily variability of dry deposition velocities show a similar shape between the control and coupled simulation (Figure 7); this suggests that the coupling through the canopy conductance modulates the amplitude of the deposition velocities leaving unchanged the daily variability, which is mainly driven by other variables (likely $2 \mathrm{~m}$ temperature).

[50] Figure 8 displays the zonal means of daily canopy conductance (upper panels) and dry deposition velocity (lower panels) as simulated by the control and coupled 
ANNUAL
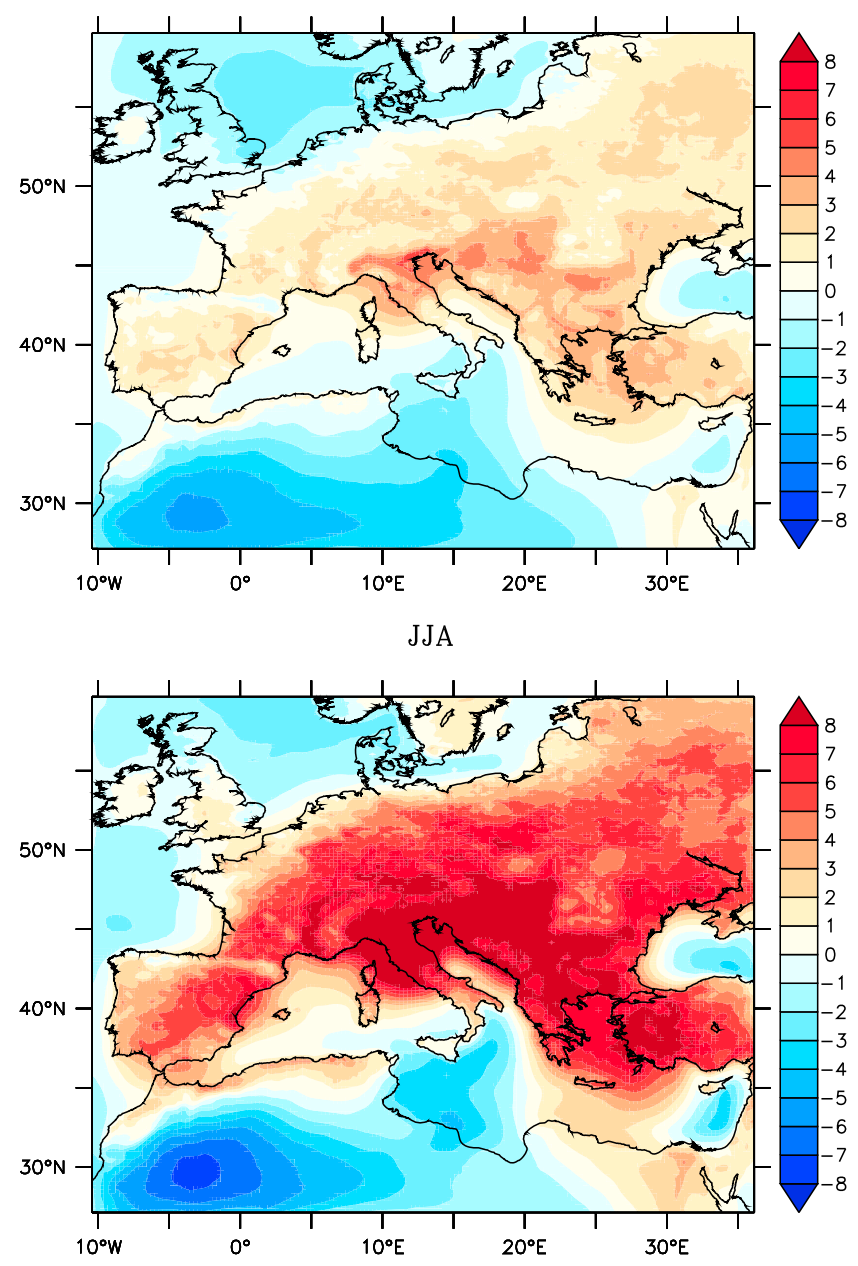

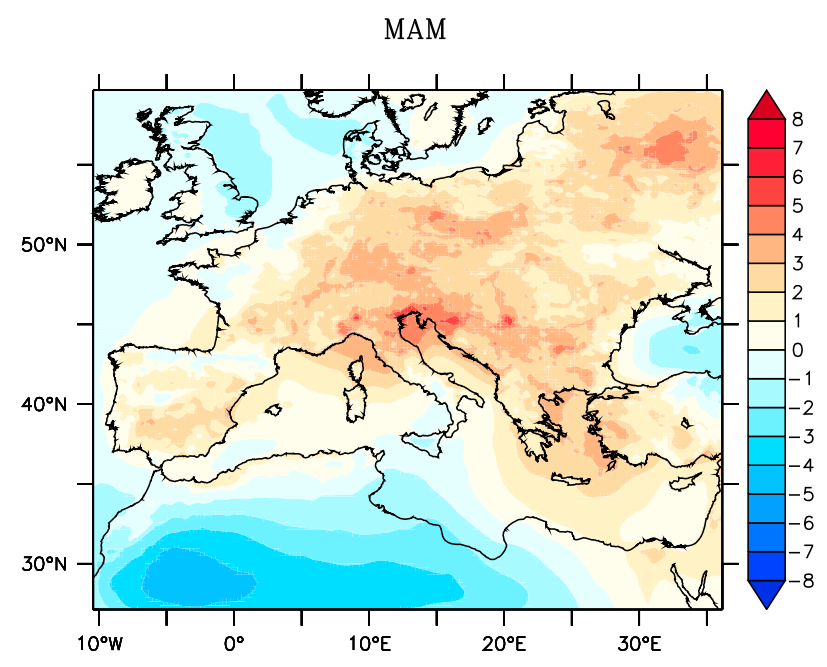

SON

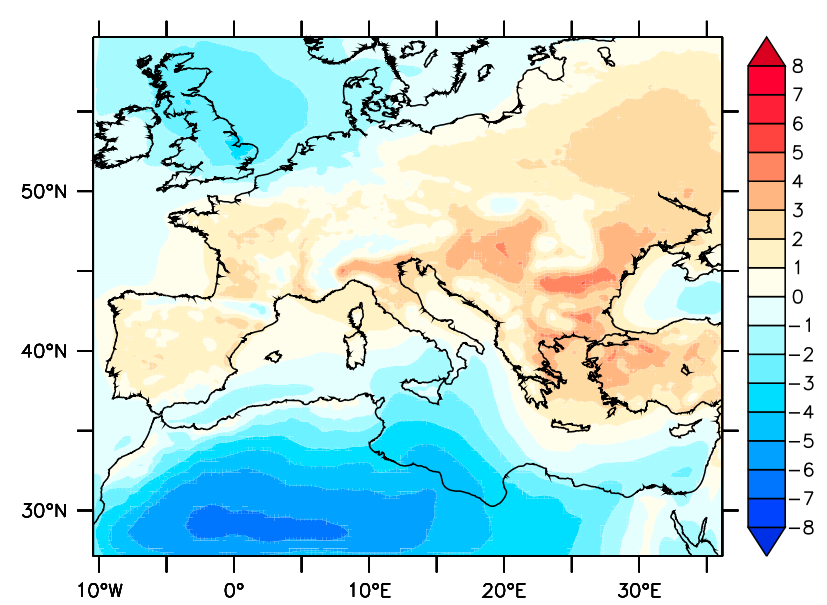

(CPL-CTL) in surface ozone concentration

Figure 10. Mean annual and seasonal anomalies (units $=\mathrm{ppb}$ ).

simulations. Considering the control run, it shows a broad maximum canopy conductance taking place between $45^{\circ} \mathrm{N}$ and $55^{\circ} \mathrm{N}$ from late May until the end of July (Figure 7). Besides, as already pointed out in Figure 5, during the winter months above $35^{\circ} \mathrm{N}$ the canopy conductance is close to zero, and this would confirm that CTL does not correctly reproduce the winter activity of evergreen forests (both temperate and boreal), cropland and grassland. Finally, below $28^{\circ} \mathrm{N}$ the canopy conductance is zero since in Northern Africa the vegetation is sparse or absent. Unlike CTL, the CPL run shows a higher canopy conductance during winter months, mainly in central Europe between $40^{\circ} \mathrm{N}$ and $50^{\circ} \mathrm{N}$, reflecting the activity of evergreen forests, cropland and grassland (Figure 8). The maximum values take place during July and it agrees with CTL results in terms of magnitude. However, while CTL shows a broad maximum value between May and July, CPL reproduce only a tiny maximum in July.

[51] The zonal mean of deposition velocity shows a consistent pattern between the control and coupled simulations. Specifically, in CTL the deposition velocity has a broad maximum between $45^{\circ} \mathrm{N}$ and $55^{\circ} \mathrm{N}$ during the whole period May-September (Figure 8), while CPL shows the higher values in the late April and lower values during summer (Figure 8). Below $35^{\circ} \mathrm{N}$ there are no significant differences between CTL and CPL, while above $55^{\circ} \mathrm{N}$ CTL is systematically higher than CPL during the period May-September as a consequence of the higher values of canopy conductance in the boreal regions.

[52] Finally, the overall impact of coupling on surface ozone concentration is shown in Figures 9 and 10. Consistently with previous analysis, $\left[\mathrm{O}_{3}\right]$ time series are presented in Figure 9 for the whole year and for the two model configurations (CTL and CPL) over the 2 different sub-domains.

[53] The general annual cycle of ozone is characterized by the higher ozone concentrations during summer, owing to the prevailing anticyclonic conditions coinciding with increased solar radiation and intensified photochemistry, high temperatures, and low wind speed. In addition, as a photochemical pollutant, the ozone formation depends on temperature, therefore in Southern Europe the ozone concentration is larger than in the Northern regions.

[54] Looking at Figure 9, during winter the coupled model simulates in both the sub-domains less ozone concentrations than the control run, being a direct effect of higher canopy 

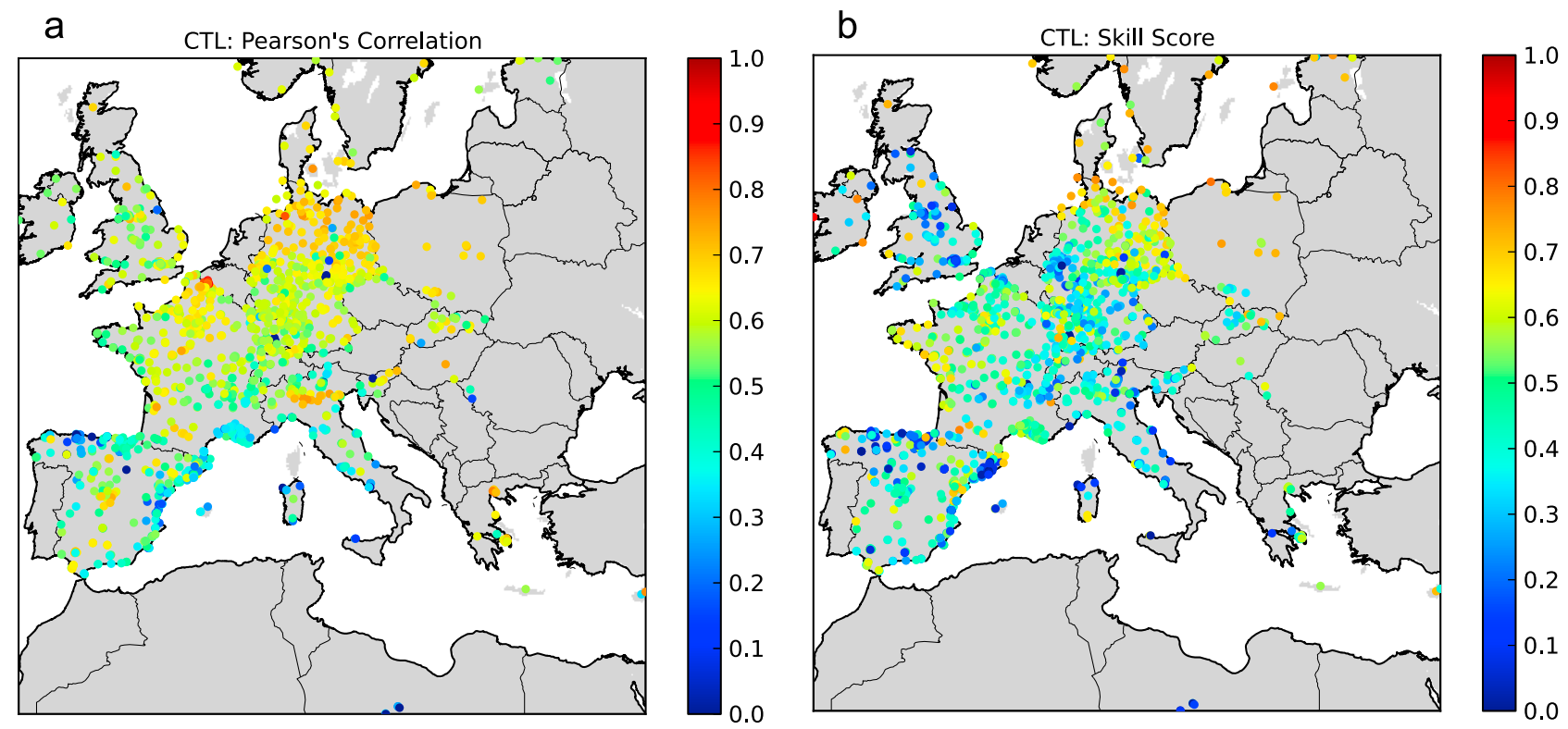

C
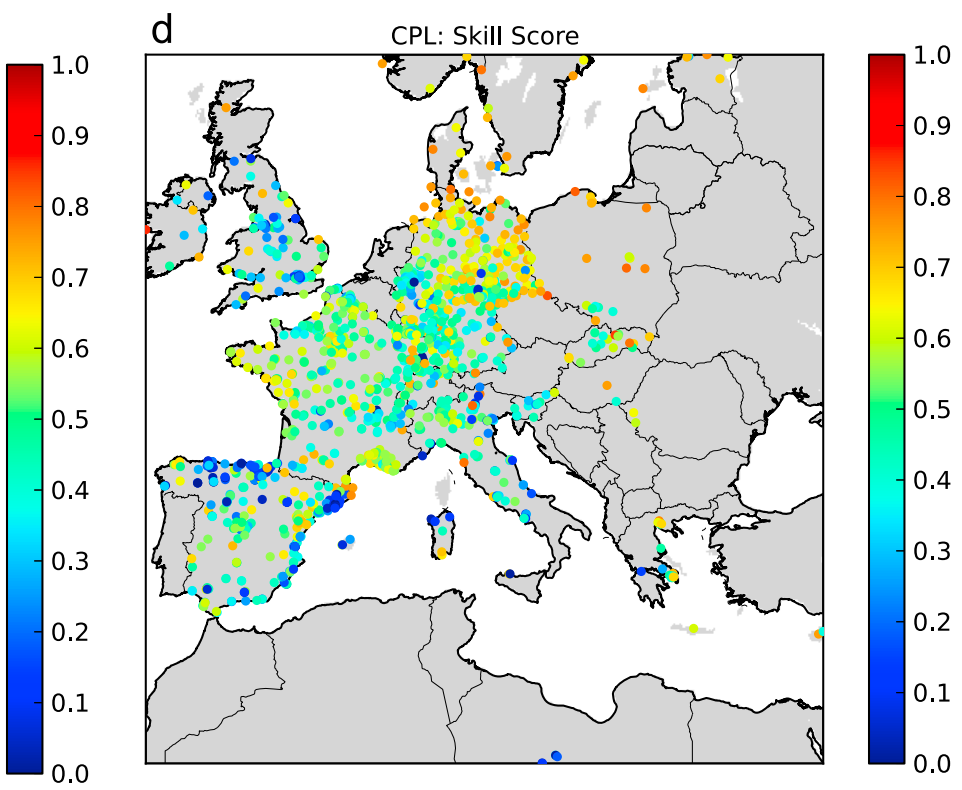

Figure 11. Correlation and skill score maps obtained comparing the mean daily ozone concentration as simulated by CHIMERE control and coupled runs with observations from AIRBASE and EMEP network at 1389 ground-based stations.

conductance (as presented in Figure 5) that enhances the dry deposition velocity (Figure 7). An inverse tendency is observed during summer, when CPL presents in average more ozone concentrations over the whole of Europe than CTL.

[55] The surface ozone concentrations anomalies are shown in Figure 10. The most important differences are found during summer when the vegetation has the maximum activity and this favors the ozone dry deposition. The spatial coverage of anomalies is homogeneous over the whole Europe, therefore this suggests that a combination of the canopy conductance changes, modified biogenic emissions and the transport of ozone (having a time life of few days) contribute to this pattern. Surprisingly, a negative anomaly is observed in the southern part of the modeled domain, in
Africa; since the changes in canopy conductance in this area are not relevant, the anomaly is likely due to the transport processes.

\section{Discussion}

[56] We have coupled at high spatial resolution a chemistry transport model with a land surface model to explore the regional feedback between vegetation and atmospheric chemistry in the Euro-Mediterranean basin. Specifically, this coupled model allows an assessment of the impact of air pollution on vegetation and an evaluation of the consequent changes in dry deposition and biogenic emissions related to the impact of pollutants on forests and crops. 

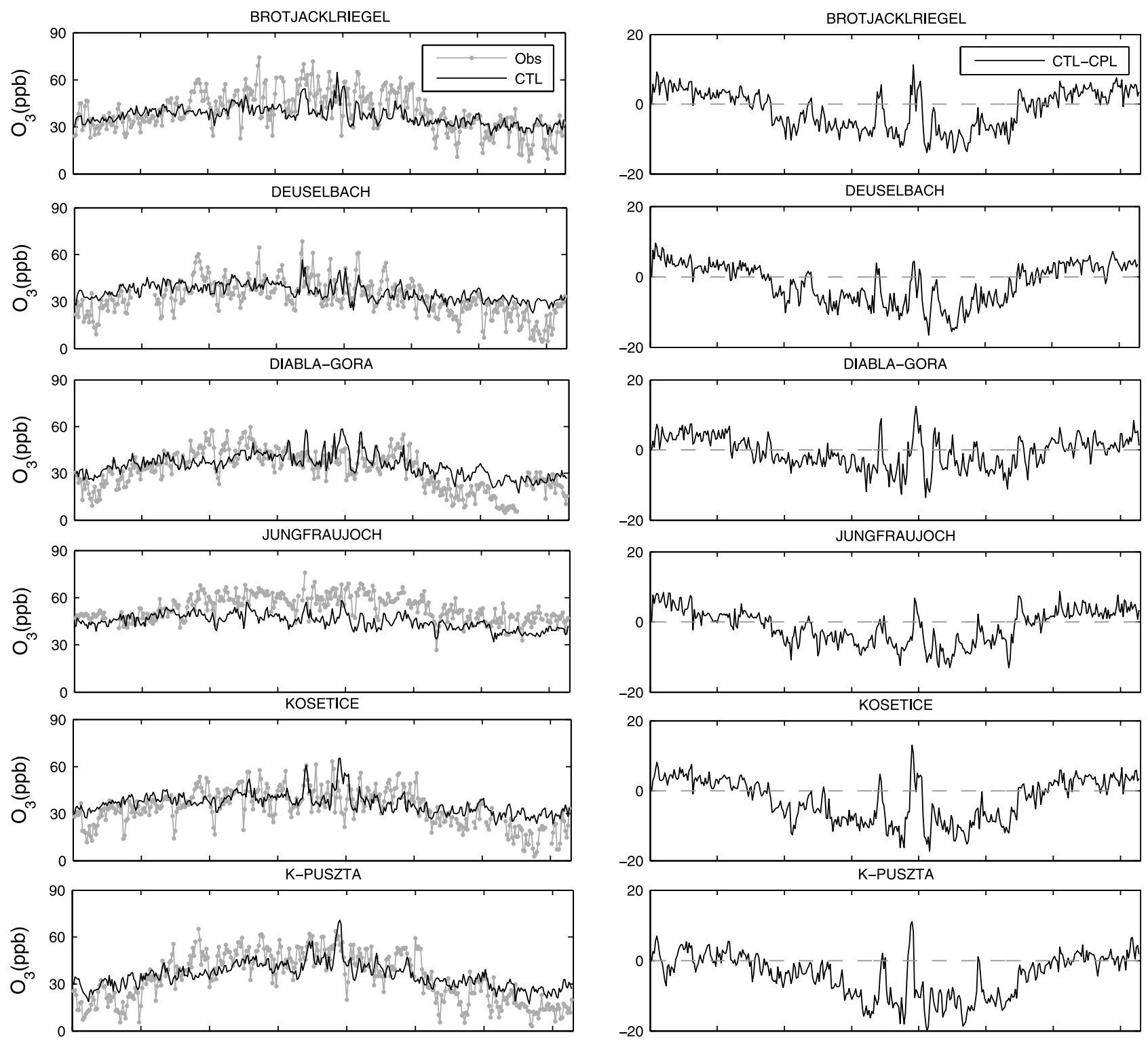

Figure 12. Observed and modeled (CTL) mean daily ozone concentration for different monitoring stations (left), and differences between CHIMERE uncoupled and coupled simulations (CPL -CTL) at the same sites (right).

[57] Considering the whole domain, our results indicate that ozone reduces the GPP by about $23 \%$. A reduction in carbon assimilation leads to a smaller amount of biomass stored and hence to a decrease of LAI.

[58] One of the main finding of this paper is the inability of CHIMERE (in the control run) to reproduce the winter and early spring activity of evergreen forests, cropland and grassland in Northern Europe. These vegetations have a photosynthetic activity year-round, namely are able to absorb the atmospheric $\mathrm{CO}_{2}$ during all year. Therefore, the canopy conductance for these vegetation types would be expected to be greater than zero over the winter months, while our results show that the canopy conductance is close to zero until March. This translates into significant differences between the control and coupled dry deposition velocities that consequently affect the surface ozone concentration.
[59] Compared to previous estimates [Ganzeveld and Lelieveld, 1995] our results indicate a lower dry deposition velocity. Specifically, Ganzeveld and Lelieveld [1995] performed a simulation with a general circulation model at very coarse spatial resolution $\left(5.6^{\circ} \times 5.6^{\circ}\right)$, and they extracted the ozone dry deposition velocities at several vegetated grid points of the domain. In the European grid point, where dominant vegetation is crop, they found a mean dry deposition velocity of $0.2 \mathrm{~cm} / \mathrm{s}$ during January, and $0.5 \mathrm{~cm} / \mathrm{s}$ in July. Our results for the whole Northern Europe domain indicate a mean velocity of $0.15 \mathrm{~cm} / \mathrm{s}$ during January and $0.25 \mathrm{~cm} / \mathrm{s}$ in July, however the mismatch is likely related to the difference in spatial resolution that leads to a more complex spatial pattern in vegetation coverage. Conversely, compared to results from Fowler et al. [2009], the coupled simulation well matches the observed values. In particular, 

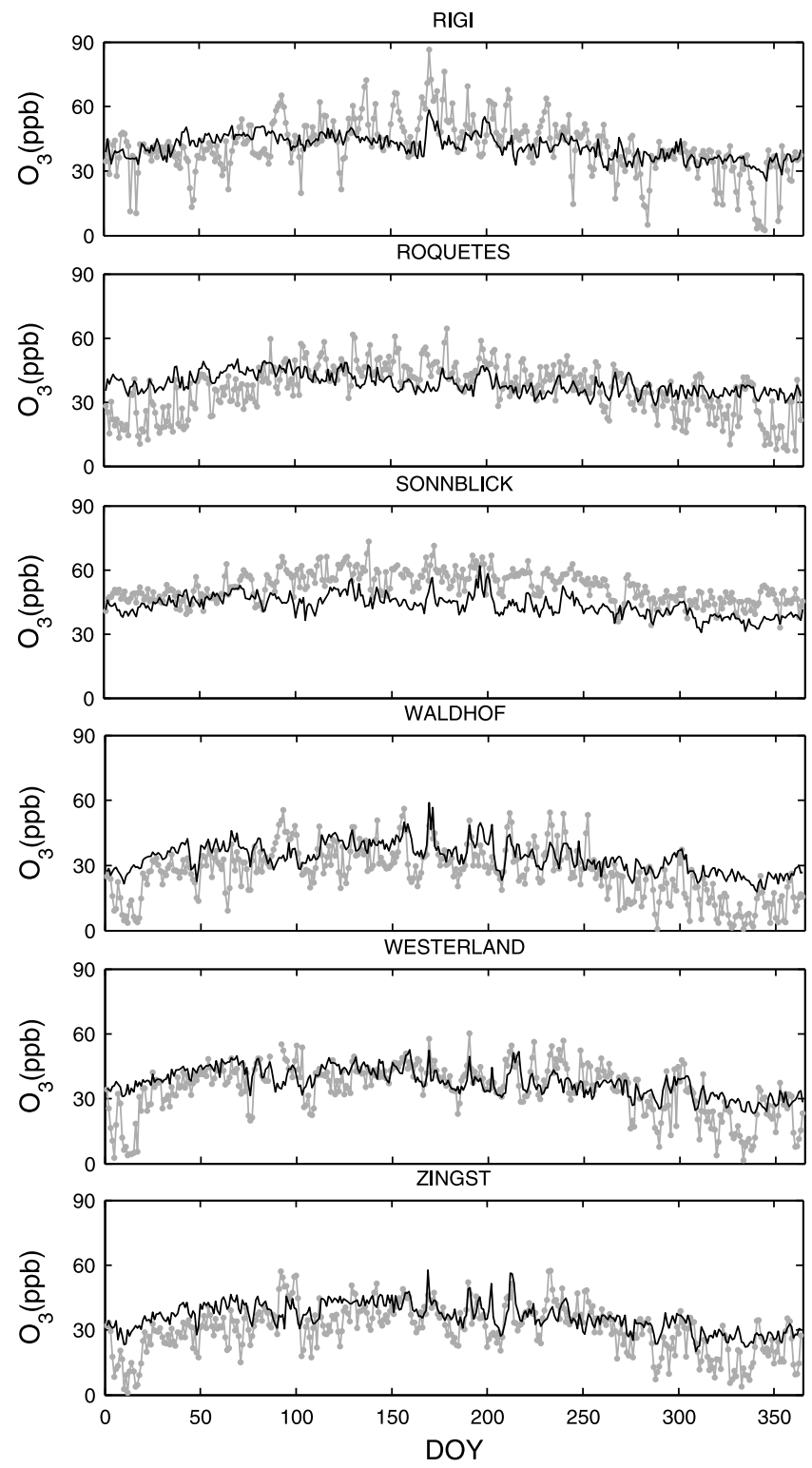

Figure 12. (continued)

in the grid points where the dominant vegetation is composed by boreal PFTs we found a summer maximum value of $0.5 \mathrm{~cm} / \mathrm{s}$ taking place between 10 and 12 A.M. Consistent with results of Fowler et al. [2009], the temperate forest sites show a mean value of $1-1.2 \mathrm{~cm} / \mathrm{s}$ during spring, with the maximum occurring between 9 and 10 A.M. (not shown).

[60] In order to investigate whether there is an improvement in the coupled version, the CHIMERE simulations are compared with observations at 1389 background monitoring sites (available from EMEP: http://www.emep.int and AirBase http://acm.eionet.europa.eu/databases/airbase/ data portal). Figure 11 displays the spatialized correlation coefficient (r) and a skill score between CHIMERE results and observations. The skill score is based on the comparison of Epanechnikov kernel-based probability density functions (PDFs) of models with observations [Errasti et al., 2011].

[61] This skill score provides a very simple but powerful measure of similarity between data and observations since it
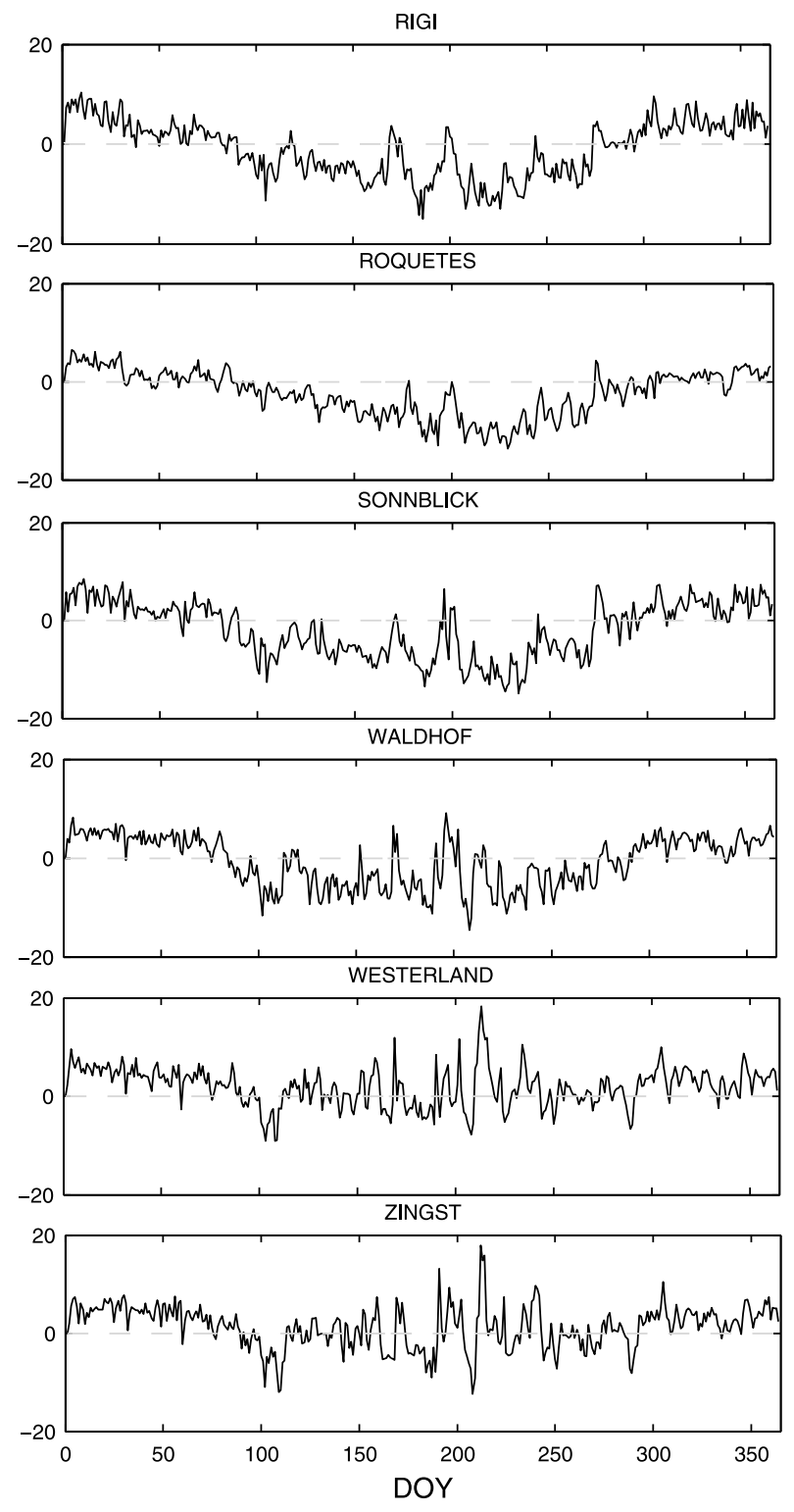

allows to compare both the mean state and the seasonal variability of a given variable by calculation of the common area under the two PDFs [Maxino et al., 2008].

[62] If models perfectly reproduce the observed condition, the skill score would equal 1 , which is the total area under a given PDF. On the contrary, if a model simulates the observed PDF poorly, it will have a skill score close to 0 , namely there is not any overlap between the observed and modeled PDF. Given $Z$ the common area under the observed $\operatorname{PDF}\left(\mathrm{Z}^{\mathrm{O}}\right)$ and the simulated $\operatorname{PDF}\left(\mathrm{Z}^{\mathrm{M}}\right)$ at a given station:

$$
Z=\min \left(z^{O}-z^{M}\right)
$$

the skill score is computed in the following way:

$$
s=\int_{1}^{N} Z,
$$


Table 1. Names, Countries, Coordinates and Altitudes of the Sites Used to Validate CHIMERE

\begin{tabular}{lcrrr}
\hline Station Name & Country & Latitude & Longitude & Altitude (m) \\
\hline Brotjacklriegel & Germany & $48.82^{\circ} \mathrm{N}$ & $13.22^{\circ} \mathrm{E}$ & 1016 \\
Deuselbach & Germany & $49.77^{\circ} \mathrm{N}$ & $7.05^{\circ} \mathrm{E}$ & 480 \\
Diabla-Gora & Poland & $54.15^{\circ} \mathrm{N}$ & $22.07^{\circ} \mathrm{E}$ & 157 \\
Jungfraujoch & Switzerland & $46.55^{\circ} \mathrm{N}$ & $7.99^{\circ} \mathrm{E}$ & 3580 \\
Kosetice & Czech Republic & $49.58^{\circ} \mathrm{N}$ & $15.08^{\circ} \mathrm{E}$ & 534 \\
K-puszta & Hungary & $46.97^{\circ} \mathrm{N}$ & $19.55^{\circ} \mathrm{E}$ & 125 \\
Rigi & Switzerland & $46.07^{\circ} \mathrm{N}$ & $8.45^{\circ} \mathrm{E}$ & 1031 \\
Roquetes & Spain & $40.82^{\circ} \mathrm{N}$ & $0.48^{\circ} \mathrm{E}$ & 50 \\
Sonnblick & Austria & $47.05^{\circ} \mathrm{N}$ & $12.95^{\circ} \mathrm{E}$ & 3106 \\
Waldhof & Germany & $52.80^{\circ} \mathrm{N}$ & $10.77^{\circ} \mathrm{E}$ & 74 \\
Westerland & Germany & $54.93^{\circ} \mathrm{N}$ & $8.32^{\circ} \mathrm{E}$ & 12 \\
Zingst & Germany & $54.43^{\circ} \mathrm{N}$ & $12.73^{\circ} \mathrm{E}$ & 1 \\
\hline
\end{tabular}

where $\mathrm{s}$ is the numerical value of the skill score $(0 \leq \mathrm{s} \leq 1)$, and $\mathrm{N}$ is the number of intervals used to discretize the PDF estimated by means of the Epanechnikov kernels (in this study, $\mathrm{N}=100$ ).

[63] In general, models that properly simulate the observed mean value of a given variable, namely they fall into the range of $\pm 1 \sigma$ of the observed PDF, are able to reproduce at least the $68.2 \%$ of the reference data.

[64] Considering the control run, the highest correlations are found over the central Europe where most of the sites show a correlation above 0.6 , whereas poor results are obtained in the Mediterranean area (Figure 11). The same considerations are in general also valid for the skill score, with relevant skills found in the Western France and Northern-Eastern Europe and poor performances in the Mediterranean sites, in Northern Italy, and United Kingdom, where the skill has a value lower than 0.4 in most of the sites.

[65] The coupled simulation show a relevant increase in the correlation over all the domain, with Mediterranean sites having now relative good performances $(\mathrm{r}>0.7)$. The mean correlation computed considering all the sites is 0.7 for the coupled run, while the control run has a mean correlation of 0.54 .

[66] The skill score of the coupled simulation shows an improvements of performance in central Europe and in some Mediterranean sites, however in the whole Southern part of the domain the performances are still poor, the skills being in general lower than 0.4, suggesting that in this region CHIMERE is not able to simulate $1 \sigma$ of the observed PDF. In any case, the skill score suggests an improvement of performances in the coupled run; specifically, the overall skill of the control run is 0.4 , while the in the coupled model the skill is 0.44 .

[67] Figure 12 shows the comparison of the temporal evolution of daily mean surface $\mathrm{O}_{3}$ concentrations with observations at 12 selected sites whose locations and altitude are plotted in Figure 1, and the main features are described in Table 1. The observations are taken from the database of the World Data Centre for Greenhouse Gases (WDCGG) (data are available from http://ds.data.jma.go.jp/gmd/wdcgg/). We selected these stations for several reasons: first, the stations are located in rural or remote mountainous areas, away from local emission sources, and therefore these are representative for the regional concentration field. Second, these sites cover different climate (and hence ecosystems) conditions, and the time series have only a limited number of gaps in the data. A detailed description of the stations and the instruments used to measure the surface ozone concentration is given at the WDCGG web site.

[68] The statistics of comparison depicted in Figure 12 are shown in Table 2, which presents the correlation coefficient (R), and Root Mean Square Error (RMSE) between the observations and CHIMERE control and coupled simulations for different seasons and for the whole year 2002.

[69] In the control run, being the simulation results overlapped to the observations in most of the panels, CHIMERE successfully reproduces the seasonal cycle of surface $\mathrm{O}_{3}$ (Figure 12, left panels). However, at some sites the performances are poor: in particular in Roquetes and Jungfraujoch the correlation coefficients representing the whole year are lower than 0.5 , while in all the remaining sites the R-values exceed 0.5 (Table 2). The values of RMSE show that the absolute concentration of surface $\mathrm{O}_{3}$ is simulated in the control run with a bias of 10-11 ppb in most cases, with an overall bias of $10.46 \mathrm{ppb}$.

[70] Even though there are large errors on some individual days, the seasonal variation is well reproduced by CTL, with minimum values around 30 to $45 \mathrm{ppb}$ during autumn and winter from the lowest to the highest station (Figure 12). Also the maximum values (generally $>60 \mathrm{ppb}$ according to the elevation of the station) are correctly simulated by the model during late spring and summer.

[71] Considering the seasonal comparison (Table 2) the poorest performances occur in MAM: in fact, the correlation coefficients have everywhere values lower than 0.3 , and in 3 sites (Deuselbach, Rigi, and Roquetes) we found a negative correlation. In the other seasons, generally the performances are better during SON than JJA (except Rigi where JJA is widely better than SON).

[72] Looking at the difference of daily mean surface ozone concentration between CHIMERE control and coupled runs (Figure 12, right panels), overall all the stations show that during winter and autumn the ozone concentration is systematically higher in the control run, while from late March there is a reversal sign (i.e., the ozone concentration is higher in the coupled run, except few isolate daily episodes). This pattern is consistent with the main finding about canopy conductance, and hence dry deposition velocities. Specifically during winter and fall the canopy conductance is larger in the coupled run, therefore there is also a larger amount of ozone removed by dry deposition, leading to an ozone concentration higher in the control simulation. From late March the control simulation shows an abrupt increase of canopy conductance that leads to a larger amount of ozone removed by dry deposition.

[73] Considering the performances of the coupled simulation for the whole year, the R-values exceed 0.6 at all sites (except Rigi), and for most of the sites it is close to 0.75 (Table 2). The values of RMSE show that the absolute concentration of surface $\mathrm{O}_{3}$ is simulated with an error lower than $10 \mathrm{ppb}$ in most of the stations, and with an overall bias of $9.68 \mathrm{ppb}$. The overall correlation coefficient of the control simulation is 0.6 , while for the coupled simulation it is 0.71 , 
Table 2. Statistical Summary of the Comparison Between Observed and Modeled Surface $\mathrm{O}_{3}$ at Observational Sites Shown in Figure 1

\begin{tabular}{|c|c|c|c|c|c|c|c|c|}
\hline Station & Seasons & OBS (Mean) & CTL (Mean) & CPL (Mean) & CTL (R) & CPL (R) & CTL (RMSE) & CPL (RMSE) \\
\hline \multirow[t]{4}{*}{ Brotjacklriegel } & MAM & $44.9 \pm 9.7$ & $40.72 \pm 3.25$ & $43.70 \pm 4.13$ & 0.09 & 0.26 & 10.76 & 9.55 \\
\hline & JJA & $49.45 \pm 10.06$ & $40.60 \pm 6.84$ & $47.21 \pm 2.84$ & 0.40 & 0.47 & 13.03 & 9.30 \\
\hline & $\mathrm{SON}$ & $32.56 \pm 9.66$ & $32.49 \pm 3.01$ & $33.17 \pm 6.11$ & 0.41 & 0.52 & 8.82 & 8.33 \\
\hline & ANNUAL & $39.29 \pm 12.40$ & $36.94 \pm 6.15$ & $38.55 \pm 8.55$ & 0.61 & 0.71 & 10.28 & 8.72 \\
\hline \multirow[t]{4}{*}{ Deuselbach } & MAM & $38.69 \pm 8.56$ & $40.50 \pm 2.95$ & $43.37 \pm 3.98$ & -0.05 & 0.32 & 9.33 & 9.39 \\
\hline & JJA & $38.56 \pm 9.80$ & $37.29 \pm 5.72$ & $44.62 \pm 2.91$ & 0.45 & 0.68 & 8.92 & 10.10 \\
\hline & SON & $26.44 \pm 7.71$ & $31.92 \pm 3.03$ & $32.38 \pm 5.14$ & 0.38 & 0.56 & 8.96 & 8.74 \\
\hline & ANNUAL & $32.03 \pm 11.32$ & $35.67 \pm 5.70$ & $37.71 \pm 8.07$ & 0.6 & 0.75 & 9.88 & 9.48 \\
\hline \multirow[t]{4}{*}{ Diabla-Gora } & MAM & $42.70 \pm 7.74$ & $39.06 \pm 3.66$ & $40.74 \pm 3.97$ & 0.26 & 0.33 & 8.44 & 7.65 \\
\hline & JJA & $39.02 \pm 6.45$ & $41.18 \pm 7.22$ & $44.34 \pm 4.01$ & 0.37 & 0.25 & 7.94 & 8.53 \\
\hline & SON & $19.28 \pm 9.84$ & $29.59 \pm 4.36$ & $30.86 \pm 5.82$ & 0.54 & 0.71 & 13.23 & 13.55 \\
\hline & ANNUAL & $31.82 \pm 12.34$ & $35.20 \pm 7.48$ & $35.89 \pm 8.49$ & 0.7 & 0.75 & 9.55 & 9.21 \\
\hline \multirow[t]{4}{*}{ Jungfraujoch } & MAM & $57.53 \pm 6.22$ & $49.01 \pm 3.21$ & $51.32 \pm 2.99$ & 0.01 & 0.53 & 10.98 & 8.13 \\
\hline & JJA & $59.59 \pm 5.89$ & $45.83 \pm 4.14$ & $52.07 \pm 2.50$ & 0.30 & 0.25 & 15.03 & 9.47 \\
\hline & SON & $48.25 \pm 6.67$ & $40.95 \pm 3.54$ & $40.82 \pm 5.93$ & 0.51 & 0.44 & 9.26 & 9.96 \\
\hline & ANNUAL & $53.29 \pm 7.90$ & $44.63 \pm 5.41$ & $46.00 \pm 7.58$ & 0.49 & 0.69 & 11.03 & 9.34 \\
\hline \multirow[t]{4}{*}{ Kosetice } & MAM & $39.44 \pm 8.58$ & $39.74 \pm 3.61$ & $43.52 \pm 4.40$ & 0.14 & 0.28 & 8.80 & 9.35 \\
\hline & JJA & $42.07 \pm 8.39$ & $40.66 \pm 7.77$ & $48.69 \pm 3.23$ & 0.25 & 0.40 & 9.97 & 10.10 \\
\hline & SON & $26.86 \pm 9.82$ & $32.05 \pm 3.42$ & $34.11 \pm 6.25$ & 0.40 & 0.64 & 10.34 & 10.41 \\
\hline & ANNUAL & $33.87 \pm 11.64$ & $36.78 \pm 6.66$ & $39.52 \pm 8.86$ & 0.57 & 0.75 & 10.01 & 9.65 \\
\hline \multirow[t]{4}{*}{ K-puszta } & MAM & $44.77 \pm 9.30$ & $39.15 \pm 4.30$ & $42.54 \pm 5.68$ & 0.30 & 0.41 & 10.60 & 8.94 \\
\hline & JJA & $46.81 \pm 8.51$ & $42.99 \pm 7.62$ & $53.60 \pm 2.98$ & 0.45 & 0.42 & 9.26 & 10.29 \\
\hline & SON & $25.27 \pm 11.85$ & $30.49 \pm 4.81$ & $34.30 \pm 7.47$ & 0.47 & 0.56 & 11.65 & 13.34 \\
\hline & ANNUAL & $33.89 \pm 15.52$ & $35.38 \pm 8.23$ & $39.56 \pm 11.14$ & 0.74 & 0.79 & 11.05 & 11.16 \\
\hline \multirow[t]{4}{*}{ Rigi } & MAM & $45.73 \pm 9.95$ & $45.64 \pm 2.71$ & $47.61 \pm 2.80$ & -0.03 & 0.17 & 10.34 & 10.01 \\
\hline & JJA & $51.20 \pm 10.25$ & $43.51 \pm 4.86$ & $50.33 \pm 2.95$ & 0.37 & 0.01 & 12.25 & 10.62 \\
\hline & SON & $34.44 \pm 9.60$ & $37.15 \pm 3.57$ & $36.77 \pm 6.40$ & 0.04 & 0.13 & 10.40 & 11.04 \\
\hline & ANNUAL & $41.17 \pm 12.80$ & $41.09 \pm 5.91$ & $42.10 \pm 8.83$ & 0.51 & 0.56 & 11.14 & 10.71 \\
\hline \multirow[t]{4}{*}{ Roquetes } & MAM & $42.93 \pm 7.90$ & $43.54 \pm 3.39$ & $45.28 \pm 2.36$ & -0.20 & 0.29 & 9.16 & 7.88 \\
\hline & JJA & $44.00 \pm 7.05$ & $37.49 \pm 3.57$ & $45.52 \pm 2.07$ & 0.33 & -0.09 & 9.36 & 7.64 \\
\hline & SON & $31.80 \pm 8.61$ & $35.39 \pm 3.25$ & $37.41 \pm 3.97$ & 0.42 & 0.65 & 8.57 & 8.74 \\
\hline & ANNUAL & $35.98 \pm 11.62$ & $38.45 \pm 5.12$ & $40.88 \pm 6.00$ & 0.41 & 0.75 & 10.96 & 9.67 \\
\hline \multirow[t]{4}{*}{ Sonnblick } & MAM & $56.13 \pm 6.25$ & $46.97 \pm 3.63$ & $49.99 \pm 3.18$ & 0.07 & 0.43 & 11.50 & 8.34 \\
\hline & JJA & $57.20 \pm 4.84$ & $45.11 \pm 4.70$ & $52.81 \pm 2.39$ & 0.48 & 0.13 & 13.01 & 6.71 \\
\hline & SON & $47.51 \pm 5.84$ & $39.95 \pm 3.47$ & $40.07 \pm 5.98$ & 0.56 & 0.47 & 8.95 & 9.61 \\
\hline & ANNUAL & $51.90 \pm 7.10$ & $43.33 \pm 5.43$ & $45.14 \pm 7.98$ & 0.53 & 0.67 & 10.44 & 8.94 \\
\hline \multirow[t]{4}{*}{ Waldhof } & MAM & $33.42 \pm 8.58$ & $37.74 \pm 4.40$ & $40.38 \pm 4.78$ & 0.07 & 0.22 & 10.27 & 11.24 \\
\hline & JJA & $34.06 \pm 9.07$ & $37.68 \pm 6.46$ & $42.05 \pm 4.14$ & 0.50 & 0.48 & 8.85 & 11.25 \\
\hline & SON & $19.16 \pm 10.18$ & $29.04 \pm 4.04$ & $29.11 \pm 6.09$ & 0.56 & 0.68 & 13.08 & 12.47 \\
\hline & ANNUAL & $26.63 \pm 11.91$ & $33.58 \pm 7.01$ & $34.38 \pm 8.88$ & 0.69 & 0.75 & 11.25 & 11.09 \\
\hline \multirow[t]{4}{*}{ Westerland } & MAM & $40.15 \pm 7.42$ & $43.10 \pm 4.26$ & $42.59 \pm 2.93$ & 0.27 & 0.17 & 8.00 & 7.85 \\
\hline & JJA & $41.27 \pm 7.59$ & $38.94 \pm 5.31$ & $37.73 \pm 3.65$ & 0.55 & 0.20 & 6.84 & 8.48 \\
\hline & SON & $29.21 \pm 11.80$ & $33.17 \pm 4.51$ & $31.58 \pm 4.87$ & 0.74 & 0.72 & 9.77 & 9.21 \\
\hline & ANNUAL & $34.40 \pm 11.84$ & $37.71 \pm 6.37$ & $35.79 \pm 6.48$ & 0.65 & 0.68 & 9.66 & 8.91 \\
\hline \multirow[t]{4}{*}{ Zingst } & MAM & $35.60 \pm 8.80$ & $40.88 \pm 4.17$ & $41.26 \pm 3.40$ & 0.09 & 0.19 & 10.72 & 10.42 \\
\hline & JJA & $36.94 \pm 8.04$ & $39.14 \pm 5.83$ & $38.74 \pm 3.71$ & 0.51 & 0.15 & 7.44 & 8.49 \\
\hline & SON & $25.78 \pm 10.42$ & $31.17 \pm 4.45$ & $30.39 \pm 5.52$ & 0.57 & 0.62 & 10.18 & 9.38 \\
\hline & ANNAUL & $30.32 \pm 11.01$ & $35.87 \pm 6.84$ & $34.62 \pm 7.33$ & 0.64 & 0.67 & 10.21 & 9.31 \\
\hline
\end{tabular}

therefore, unlike results found by Anav et al. [2011], this coupling significantly improves the model performances for the atmospheric chemistry.

[74] According to the annual results, also the seasonal performances are improved in the coupled simulation (Table 2): in particular during spring the coupled simulation better reproduces the temporal evolution of surface ozone concentration (Figure 12), with an error generally lower than control simulation (Table 2).

\section{Conclusion}

[75] The results of this work suggest that improving the land surface representation into a chemical transport model 
through a complex land surface model that takes into account several complex processes on the land surface, the performance of CTM itself would be improved.

[76] Since CTMs make use of look-up tables to represent some processes occurring at land surface, the extreme events like heat waves, drought and heavy rain do not affect processes related to the vegetation activity (e.g., GPP, LAI) that in turn influence the atmospheric chemistry, while coupled CTMs-land surface models would allow a better representation of these processes. Therefore, a new generation of CTMs fully coupled with complex land surface model is needed to better represent feedbacks with the vegetation and more in general the atmospheric chemistry at surface level.

[77] Although this study is useful to bridge the gap between land surface processes and atmospheric chemistry interactions, this model configuration is still coarse since it lacks of some parts, like the coupling between the micrometeorology and land surface processes that affects the planetary boundary layer stability and consequently some of the atmospheric chemistry processes taking place in the PBL. In addition this study does not explore the contribution of non-stomatal deposition to the surface resistance.

[78] On the other hand, we believe this study is useful to highlight the main feedbacks between vegetation and atmospheric chemistry and assess the changes of relevant variables like surface ozone concentration and carbon sequestration. Besides we are taking a consistent effort to set up a platform containing a fully coupled Earth system model [Drobinski et al., 2012] in which all these feedbacks are simultaneously represented.

[79] Acknowledgments. The authors would like to acknowledge the entire staffs of WDCGG for providing ground based ozone data through the WDCGG database. Other ground-based ozone measurements were downloaded from the European Air Quality Database. This work was funded by CIRCE-EU project. The authors also thank two anonymous reviewers for their helpful reviews of the manuscript.

\section{References}

Adams, R. M., D. J. Glyer, S. L. Johnson, and B. A. McCarl (1989), A reassessment of the economic effects of ozone on United States agriculture, J. Air Waste Manage. Assoc., 39, 960-968.

Allard, V., J. M. Ourcival, S. Rambal, R. Joffre, and A. Rocheteau (2008), Seasonal and annual variation of carbon exchange in an evergreen Mediterranean forest in southern France, Global Change Biol., 14, 714-725, doi:10.1111/j.1365-2486.2008.01539.x.

Altimir, N., P. Kolari, J.-P. Tuovinen, T. Vesala, J. Back, T. Suni, M. Kulmala and P. Hari (2006), Foliage surface ozone deposition: A role for surface moisture?, Biogeosciences, 3, 209-228, doi:10.5194/bg-3-209-2006.

Anav, A., F. D'Andrea, N. Viovy, and N. Vuichard (2010), A validation of heat and carbon fluxes from high resolution land-surface and regional models, J. Geophys. Res., 115, G04016, doi:10.1029/2009JG001178.

Anav, A., L. Menut, D. Khvorostyanov, and N. Viovy (2011), Impact of Tropospheric ozone on the Euro-Mediterranean vegetation, Global Change Biol., 17, 2342-2359, doi:10.1111/j.1365-2486.2010.02387.x.

Arora, V. (2002), Modeling vegetation as a dynamic component in soilvegetation-atmosphere transfer schemes and hydrological models, Rev. Geophys., 40(2), 1006, doi:10.1029/2001RG000103.

Ashmore, M. R. (2005), Assessing the future global impacts of ozone on vegetation, Plant Cell Environ., 28, 949-964, doi:10.1111/j.1365-3040. 2005.01341.x.

Atkinson, R., and J. Arey (2003), Gas-phase tropospheric chemistry of biogenic volatile organic compounds: A review, Atmos. Environ., 37, 197-219, doi:10.1016/S1352-2310(03)00391-1.

Baldocchi, D. D., B. B. Hicks, and P. Camara (1987), A canopy stomatal resistance model for gaseous deposition to vegetated surfaces, Atmos. Environ., 21, 91-101, doi:10.1016/0004-6981(87)90274-5.

Baldocchi, D. D., B. B. Hicks, and T. P. Meyers (1988), Measuring biosphere-atmosphere exchanges of biologically related gases with micrometeorological methods, Ecology, 69, 1331-1340, doi:10.2307/1941631.
Ball, J. T., I. E. Woodrow, and J. A. Berry (1987), A model predicting stomatal conductance and its contribution to the control of photosynthesis under different environmental conditions, in Progress in Photosynthesis Research, vol. 4, edited by J. Biggins, pp. 221-224, Martinus Nijhoff, Dordrecht, Netherlands.

Beer, C., et al. (2010), Terrestrial gross carbon dioxide uptake: Global distribution and covariation with climate, Science, 329, 834-838, doi:10.1126/ science. 1184984

Bergin, M. H., R. Greenwald, J. Xu, Y. Berta, and W. L. Chameides (2001), Influence of aerosol dry deposition on photosynthetically active radiation available to plants: A case study in the Yangtze Delta Region of China, Geophys. Res. Lett., 28(18), 3605-3608, doi:10.1029/2001GL013461.

Bessagnet, B., A. Hodzic, R. Vautard, M. Beekmann, S. Cheinet, C. Honore, C. Liousse, and L. Rouil (2004), Aerosol modeling with CHIMEREpreliminary evaluation at the continental scale, Atmos. Environ., 38, 2803-2817, doi:10.1016/j.atmosenv.2004.02.034.

Bessagnet, B., L. Menut, G. Curci, A. Hodzic, B. Guillaume, C. Liousse, S. Moukhtar, B. Pun, C. Seigneur, and M. Schulz (2008), Regional modeling of carbonaceous aerosols over Europe-Focus on secondary organic aerosols, J. Atmos. Chem., 61, 175-202, doi:10.1007/s10874-009-9129-2.

Bessagnet, B., C. Seigneur, and L. Menut (2010), Impact of dry deposition of semi-volatile organic compounds on secondary organic aerosols, Atmos. Environ., 44, 1781-1787, doi:10.1016/j.atmosenv.2010.01.027.

Büker, P., et al. (2007), Comparison of different stomatal conductance algorithms for ozone flux modelling, Environ. Pollut., 146, 726-735, doi:10.1016/j.envpol.2006.04.007.

Curci, G., M. Beekmann, R. Vautard, G. Smiatek, R. Steinbrecher, J. Theloke, and R. Friedrich (2009), Modelling study of the impact of isoprene and terpene biogenic emissions on European ozone levels, Atmos. Environ., 43, 1444-1455, doi:10.1016/j.atmosenv.2008.02.070.

Drobinski, P., et al. (2012), Modelling the Regional Coupled Earth system (MORCE): Application to process and climate studies in vulnerable regions, Environ. Model. Softw., 35, 1-18, doi:10.1016/j.envsoft.2012.01.017. Ducoudré, N. I., K. Laval, and A. Perrier (1993), SECHIBA, a new set of parameterizations of the hydrologic exchanges at the land-atmosphere interface within the LMD atmospheric general circulation model, J. Clim., 6, 248-273, doi:10.1175/1520-0442(1993)006<0248:SANSOP $>2.0 . C O ; 2$.

Emberson, L. D., M. R. Ashmore, H. M. Cambridge, J. P. Tuovinen, and D. Simpson (2000), Modelling stomatal flux across Europe, Environ. Pollut., 109, 403-413, doi:10.1016/S0269-7491(00)00043-9.

Erisman, J. W., A. Van Pul, and G. P. Wyers (1994), Parameterization of surface resistance for the quantification of atmospheric deposition of acidifying pollutants and ozone, Atmos. Environ., 28, 2595-2607, doi:10.1016/1352-2310(94)90433-2.

Errasti, I., A. Ezcurra, J. Sáenz, and G. Ibarra-Berastegi (2011), Validation of IPCC AR4 models over the Iberian Peninsula, Theor. Appl. Climatol., 103, 61-79, doi:10.1007/s00704-010-0282-y.

Farquhar, G. D., S. Von Caemmerer, and J. A. Berry (1980), A biochemical model of photosynthetic $\mathrm{CO}_{2}$ assimilation in leaves of $\mathrm{C} 3$ species, Planta, 149, 78-90, doi:10.1007/BF00386231.

Fehsenfeld, F., et al. (1992), Emissions of volatile organic compounds from vegetation and the implications for atmospheric chemistry, Global Biogeochem. Cycles, 6(4), 389-430, doi:10.1029/92GB02125.

Felzer, B. S., D. Kicklighter, J. Melillo, C. Wang, Q. Zhuang, and R. Prinn (2004), Effects of ozone on net primary production and carbon sequestration in the conterminous United States using a biogeochemistry model, Tellus, Ser. B, 56, 230-248, doi:10.1111/j.1600-0889.2004.00097.x.

Felzer, B. S., J. M. Reilly, D. W. Kicklighter, M. Sarofim, C. Wang, R. G. Prinn, and Q. Zhuang (2005), Future effects of ozone on carbon sequestration and climate change policy using a global biochemistry model, Clim. Change, 73, 345-373, doi:10.1007/s10584-005-6776-4.

Foley, J. A., J. E. Kutzbach, M. T. Coe, and S. Levis (1994), Feedbacks between climate and boreal forests during the Holocene epoch, Nature, 371, 52-54, doi:10.1038/371052a0

Fowler, D., C. Flechard, J. N. Cape, R. L. Storeton-West, and M. Coyle (2001), Measurements of ozone deposition to vegetation quantifying the flux, the stomatal and non-stomatal components, Water Air Soil Pollut., 130, 63-74, doi:10.1023/A:1012243317471.

Fowler, D., et al. (2009), Atmospheric composition change: Ecosystemsatmosphere interactions, Atmos. Environ., 43, 5193-5267, doi:10.1016/ j.atmosenv.2009.07.068.

Fuhrer, J., and F. Booker (2003), Ecological issues related to ozone: Agricultural issues, Environ. Int., 29, 141-154, doi:10.1016/S0160-4120(02) 00157-5.

Galmés, J., H. Medrano, and J. Flexas (2007), Photosynthetic limitations in response to water stress and recovery in Mediterranean plants with different growth forms, New Phytol., 175, 81-93, doi:10.1111/j.14698137.2007.02087.x. 
Ganzeveld, L., and J. Lelieveld (1995), Dry deposition parameterization in a chemistry general circulation model and its influence on the distribution of reactive trace gases, J. Geophys. Res., 100(D10), 20,999-21,012, doi:10.1029/95JD02266.

Ganzeveld, L., D. Helmig, C. W. Fairall, J. Hare, and A. Pozzer (2009), Atmosphere- ocean ozone exchange: A global modeling study of biogeochemical, atmospheric, and waterside turbulence dependencies, Global Biogeochem. Cycles, 23, GB4021, doi:10.1029/2008GB003301.

Granier, A., et al. (2007), Evidence for soil water control on carbon and water dynamics in European forests during the extremely dry year: 2003, Agric. For. Meteorol., 143, 123-145, doi:10.1016/j.agrformet. 2006.12.004.

Grünhage, L., H. D. Haenel, and H. J. Jager (2000), The exchange of ozone between vegetation and atmosphere: Micrometeorological measurement techniques and models, Environ. Pollut., 109, 373-392, doi:10.1016/ S0269-7491(00)00041-5.

Guenther, A., et al. (1995), A global model of natural volatile organic compound emissions, J. Geophys. Res., 100(D5), 8873-8892, doi:10.1029/ 94JD02950.

Guenther, A., T. Karl, P. Harley, C. Wiedinmyer, P. I. Palmer, and C. Geron (2006), Estimates of global terrestrial isoprene emissions using MEGAN (Model of Emissions of Gases and Aerosols from Nature), Atmos. Chem. Phys., 6, 3181-3210, doi:10.5194/acp-6-3181-2006.

Gutschick, V. P., and T. Simonneau (2002), Modelling stomatal conductance of fieldgrown sunflower under varying soil water content and leaf environment: Comparison of three models of stomatal response to leaf environment and coupling with an abscisic acid-based model of stomatal response to soil drying, Plant Cell Environ., 25, 1423-1434, doi:10.1046/ j.1365-3040.2002.00937.x.

Hauglustaine, D. A., C. Granier, G. P. Brasseur, and G. Mégie (1994), The importance of atmospheric chemistry in the calculation of radiative forcing on the climate system, J. Geophys. Res., 99(D1), 1173-1186, doi:10.1029/93JD02987.

Heagle, A. S. (1989), Ozone and crop yield, Annu. Rev. Phytopathol., 27, 397-423, doi:10.1146/annurev.py.27.090189.002145.

Heagle, A. S., J. S. Mille, F. L. Booker, and W. A. Pursley (1999), Ozone stress, carbon dioxide enrichment, and nitrogen fertility interactions in cotton, Crop Sci., 39, 731-741, doi:10.2135/cropsci1999. 0011183X003900030021x.

Hicks, B. B., and D. R. Matt (1988), Combining biology, chemistry, and meteorology in modeling and measuring dry deposition, J. Atmos. Chem., 6, 117-131, doi:10.1007/BF00048335.

Hoff, C., S. Rambal, and R. Joffre (2002), Simulating carbon and water flows and growth in a Mediterranean evergreen Quercus ilex coppice using the FOREST-BGC model, For. Ecol. Manage., 164, 121-136, doi:10.1016/S0378-1127(01)00605-3.

Jarvis, P. G. (1976), The interpretation of the variations in leaf water potential and stomatal conductance found in canopies in the field, Philos. Trans. R. Soc. London B, 273, 593-610, doi:10.1098/rstb.1976.0035.

Jung, M., M. Reichstein, and A. Bondeau (2009), Towards global empirical upscaling of FLUXNET eddy covariance observations: Validation of a model tree ensemble approach using a biosphere model, Biogeosciences, 6, 2001-2013, doi:10.5194/bg-6-2001-2009.

Jung, M., et al. (2011), Global patterns of land-atmosphere fluxes of carbon dioxide, latent heat, and sensible heat derived from eddy covariance, satellite, and meteorological observations, J. Geophys. Res., 116, G00J07, doi:10.1029/2010JG001566.

Karnosky, D. F., et al. (2007), Free-air exposure systems to scale up ozone research to mature trees, Plant Biol., 9, 181-190, doi:10.1055/s-2006955915 .

Katul, G. G., T. Grönholm, S. Launiainen, and T. Vesala (2011), The effects of the canopy medium on dry deposition velocities of aerosol particles in the canopy sub-layer above forested ecosystems, Atmos. Environ., 45, 1203-1212, doi:10.1016/j.atmosenv.2010.06.032.

Keenan, T., R. Garća, A. D. Friend, S. Zaehle, C. Gracia, and S. Sabate (2009), Improved understanding of drought controls on seasonal variation in Mediterranean forest canopy $\mathrm{CO}_{2}$ and water fluxes through combined in situ measurements and ecosystem modelling, Biogeosci. Discuss., 6, 2285-2329, doi:10.5194/bgd-6-2285-2009.

Krinner, G., N. Viovy, N. de Noblet-Ducoudré, J. Ogée, J. Polcher, P. Friedlingstein, P. Ciais, S. Sitch, and I. C. Prentice (2005), A dynamic global vegetation model for studies of the coupled atmospherebiosphere system, Global Biogeochem. Cycles, 19, GB1015, doi:10.1029/ 2003GB002199.

Lathière, J., D. A. Hauglustaine, A. D. Friend, N. De Noblet-Ducoudré, N. Viovy, and G. A. Folberth (2006), Impact of climate variability and land use changes on global biogenic volatile organic compound emissions, Atmos. Chem. Phys., 6, 2129-2146, doi:10.5194/acp-6-2129-2006.
Martin, M. J., G. E. Host, and K. E. Lenz (2001), Stimulating the growth response of aspen to elevated ozone: A mechanistic approach to scaling a leaf-level model of ozone effects on photosynthesis to a complex canopy architecture, Environ. Pollut., 115, 425-436, doi:10.1016/S0269. 7491(01)00232-9.

Matyssek, R., et al. (2007), Synopsis of the CASIROZ case study: Carbon sink strength of Fagus sylvatica L. in a changing environment Experimental risk assessment of mitigation by chronic ozone impact, Plant Biol., 9, 163-180, doi:10.1055/s-2007-964883.

Matyssek, R., D. Karnosky, M. Kubiske, E. Oksanen, and G. Wieser (2010a), Advances in understanding ozone impact on forest trees: Messages from novel phytotron and free-air fumigation studies, Environ. Pollut., 158, 1990-2006, doi:10.1016/j.envpol.2009.11.033.

Matyssek, R., et al. (2010b), Enhanced ozone strongly reduces carbon sink strength of adult beech (Fagus sylvatica)-Resume from the free-air fumigation study at Kranzberg Forest, Environ. Pollut., 158, 2527-2532, doi:10.1016/j.envpol.2010.05.009.

Maxino, C. C., B. J. McAvaney, A. J. Pitman, and S. E. Perkins (2008), Ranking the AR4 climate models over the Murray-Darling Basin using simulated maximum temperature, minimum temperature and precipitation, Int. J. Climatol., 28, 1097-1112, doi:10.1002/joc.1612.

Mikkelsen, T. N., H. Ro-Poulsen, M. F. Hovmand, N. O. Jensen, K. Pilegaard, and A. H. Egeløøv (2004), Five-year measurements of ozone fluxes to a Danish Norway spruce canopy, Atmos. Environ., 38, 2361-2371, doi:10.1016/j.atmosenv.2003.12.036.

Muntifering, R. B., A. Chappelka, J. C. Lin, D. F. Karnosky, and G. L. Somers (2006), Chemical composition and digestibility of Trifolium exposed to elevated ozone and carbon dioxide in a free-air (FACE) fumigation system, Funct. Ecol., 20, 269-275, doi:10.1111/j.1365-2435. 2006.01093.x

Nunn, A. J., I. M. Reiter, K. H. Haeberle, H. Werner, C. Langebartels, H. Sandermann, C. Heerdt, P. Fabian, and R. Matyssek (2002), 'Free-air' ozone canopy fumigation in an old-growth mixed forest: Concept and observations in beech, Phyton (Buenos Aires), 42, 105-119.

Nunn, A. J., et al. (2005), Comparison of ozone uptake and sensitivity between a phytotron study with young beech and a field experiment with adult beech (Fagus sylvatica), Environ. Pollut., 137, 494-506, doi:10.1016/j.envpol.2005.01.036.

Ollinger, S. V., J. D. Aber, and B. Reich (1997), Simulating ozone effects on forest productivity: Interactions among leaf-, canopy-, and stand-level processes, Ecol. Appl., 7, 1237-1251, doi:10.1890/1051-0761(1997)007 [1237:SOEOFP]2.0.CO;2.

Padro, J., G. Den Hartog, and H. H. Neumann (1991), An Investigation of the ADOM dry deposition module using summertime $\mathrm{O}_{3}$ measurements above a deciduous forest, Atmos. Environ., 25, 1689-1704, doi:10.1016/ 0960-1686(91)90027-5.

Padro, J., H. H. Neumann, and G. Den Hartog (1992), Modelled and observed dry deposition velocity of $\mathrm{O}_{3}$ above a deciduous forest in the winter, Atmos. Environ., 26, 775-784, doi:10.1016/0960-1686(92) 90237-F.

Petroff, A., A. Mailliat, M. Amielh, and F. Anselmet (2008), Aerosol dry deposition on vegetative canopies. Part 1: Review of present knowledge, Atmos. Environ., 42, 3625-3653, doi:10.1016/j.atmosenv.2007.09.043.

Pielke, R. A., R. Avissar, M. Raupach, H. Dolman, X. Zeng, and S. Denning (1998), Interactions between the atmosphere and terrestrial ecosystems: Influence on weather and climate, Global Change Biol., 4, 461-475, doi:10.1046/j.1365-2486.1998.t01-1-00176.x.

Prentice, I. C., M. Heimann, and S. Sitch (2000), The carbon balance of the terrestrial biosphere: Ecosystem models and atmospheric observations, Ecol. Appl., 10, 1553-1573, doi:10.1890/1051-0761(2000)010[1553: TCBOTT]2.0.CO;2.

Reich, P. B. (1987), Quantifying plant response to ozone: A unifying theory, Tree Physiol., 3, 63-91.

Ren, W., H. Tian, M. Liu, C. Zhang, G. Chen, S. Pan, B. Felzer, and X. Xu (2007), Effects of tropospheric ozone pollution on net primary productivity and carbon storage in terrestrial ecosystems of China, J. Geophys. Res., 112, D22S09, doi:10.1029/2007JD008521.

Ruijgrok, W., C. I. Davidson, and K. W. Nicholson (1995), Dry deposition of particles: Implications and recommendations for mapping of deposition over Europe, Tellus, Ser. B, 47, 587-601, doi:10.1034/j.1600-0889. 1996.t01-3-00009.x

Sala, A., and J. D. Tenhunen (1996), Simulations of canopy net photosynthesis and transpiration in Quercus Ilex L. under the influence of seasonal drought, Agric. For. Meteorol., 78, 203-222, doi:10.1016/0168-1923(95) 02250-3.

Schmidt, H., C. Derognat, R. Vautard, and M. Beekmann (2001), A comparison of simulated and observed $\mathrm{O}_{3}$ mixing ratios for the summer of 1998 in Western Europe, Atmos. Environ., 35, 6277-6297, doi:10.1016/ S1352-2310(01)00451-4. 
Seinfeld, J. H., and S. N. Pandis (2006), Atmospheric Chemistry and Physics: From Air Pollution to Climate Change, 2nd ed., pp. 450-460, John Wiley and Sons, New York, ISBN 978-0-471-72018-8.

Simpson, D., et al. (1999), Inventorying emissions from nature in Europe, J. Geophys. Res., 104(D7), 8113-8152, doi:10.1029/98JD02747.

Sitch, S., et al. (2003), Evaluation of ecosystem dynamics, plant geography and terrestrial carbon cycling in the LPJ dynamic global vegetation model, Global Change Biol., 9, 161-185, doi:10.1046/j.1365-2486. 2003.00569.x

Sitch, S., P. Cox, W. J. Collins, and C. Huntingford (2007), Indirect radiative forcing of climate change through ozone effects on the land-carbon sink, Nature, 448, 791-794, doi:10.1038/nature06059.

Skamarock, W. C., J. B. Klemp, J. Dudhia, D. O. Gill, D. M. Barker, W. Wang, and J. G. Powers (2005), A description of the advanced research WRF, Version 2, NCAR Tech. Note $468+(S T R), 88$ pp., Natl. Cent. for Atmos. Res., Boulder, Colo.

Solmon, F., C. Sarrat, D. Serça, P. Tulet, and R. Rosset (2004), Isoprene and monoterpenes biogenic emissions in France: Modeling and impact during a regional pollution episode, Atmos. Environ., 38, 3853-3865, doi:10.1016/j.atmosenv.2004.03.054.

Stella, P., et al. (2011), Predicting and partitioning ozone fluxes to maize crops from sowing to harvest: The Surfatm- $\mathrm{O}_{3}$ model, Biogeosciences, 8, 2869-2886, doi:10.5194/bg-8-2869-2011.

Thunis, P., and C. Cuvelier (2000), Impact of biogenic emissions on ozone formation in the Mediterreanean area - A BEMA modelling study, Atmos. Environ., 34, 467-481, doi:10.1016/S1352-2310(99)00313-1.

Valkama, E., J. Koricheva, and E. Oksanen (2007), Effects of elevated $\mathrm{O}_{3}$, alone and in combination with elevated $\mathrm{CO}_{2}$, on tree leaf chemistry and insect herbivore performance: A meta-analysis, Global Change Biol., 13, 184-201, doi:10.1111/j.1365-2486.2006.01284.x.
Vautard, R., B. Bessagnet, M. Chin, and L. Menut (2005), On the contribution of natural Aeolian sources to particulate matter concentrations in Europe: Testing hypotheses with modelling approach, Atmos. Environ. 39, 3291-3303, doi:10.1016/j.atmosenv.2005.01.051

Vestreng, V. (2003), Review and revision: Emission data reported to CLRTAP, MSC-W Status Rep. 2003, Note 1/2003, 134 pp., Oslo Meteorol. Inst., Oslo, ISSN 0804-2446.

Weinstein, D. A., L. J. Samuelson, and M. A. Arthur (1998), Comparison of the response of red oak (Quercus rubra) seedlings and mature trees to ozone exposure using simulation modeling, Environ. Pollut., 102, 307-320, doi:10.1016/S0269-7491(98)00049-9.

Werner, H., and P. Fabian (2002), Free-air fumigation of mature trees, Environ. Sci. Pollut. Res., 9, 117-121, doi:10.1007/BF02987458.

Wesely, M. L. (1989), Parameterisation of surface resistances to gaseous dry deposition in regional-scale numerical models, Atmos. Environ., 23, 1293-1304, doi:10.1016/0004-6981(89)90153-4.

Wittig, V. E., E. A. Ainsworth, and S. P. Long (2007), To what extent do current and projected increases in surface ozone affect photosynthesis and stomatal conductance of trees? A meta-analytic review of the last 3 decades of experiments, Plant Cell Environ., 30, 1150-1162, doi:10.1111/j.1365-3040.2007.01717x

Wittig, V. E., E. A. Ainsworth, S. L. Naidu, D. F. Karnosky, and S. P. Long (2009), Quantifying the impact of current and future tropospheric ozone on tree biomass, growth, physiology and biochemistry: A quantitative meta-analysis, Global Change Biol., 15, 396-424, doi:10.1111/j.13652486.2008.01774.x.

Zhang, L., J. R. Brook, and R. Vet (2003), A revised parameterization for gaseous dry deposition in air-quality models, Atmos. Chem. Phys., 3, 2067-2082, doi:10.5194/acp-3-2067-2003. 